\title{
Resilience (Republished)
}

\author{
Carl Folke $^{1,2}$
}

\begin{abstract}
.
Resilience thinking in relation to the environment has emerged as a lens of inquiry that serves a platform for interdisciplinary dialogue and collaboration. Resilience is about cultivating the capacity to sustain development in the face of expected and surprising change and diverse pathways of development and potential thresholds between them. The evolution of resilience thinking is coupled to socialecological systems and a truly intertwined human-environment planet. Resilience as persistence, adaptability, and transformability of complex adaptive social-ecological systems is the focus, clarifying the dynamic and forward-looking nature of the concept. Resilience thinking emphasizes that social-ecological systems, from the individual, to community, to society as a whole, are embedded in the biosphere. The biosphere connection is an essential observation if sustainability is to be taken seriously. In the continuous advancement of resilience thinking there are efforts aimed at capturing resilience of social-ecological systems and finding ways for people and institutions to govern social-ecological dynamics for improved human well-being, at the local, across levels and scales, to the global. Consequently, in resilience thinking, development issues for human well-being, for people and planet, are framed in a context of understanding and governing complex social-ecological dynamics for sustainability as part of a dynamic biosphere.
\end{abstract}

This invited article is a republication of Folke, C. 2016. "Resilience" of the Oxford Research Encyclopedia of Environmental Science (http://dx.doi.org/10.1093/acrefore/9780199389414.013.8)

Key Words: development; resilience; social-ecological; sustainability; transformation

\section{INTRODUCTION}

The last fifteen years have seen an explosion of resilience research. The number of scientific publications on resilience in relation to the environment has during this period increased from some 250 to well over 6000 publications. The annual citations have jumped from less than 100 in year 1995 to more than 20,000 citations in 2015 (ISI Web of Science December 2015). A search on resilience and the environment at Google Scholar presents over one million hits (February 2016). Resilience is a concept and lens found in many academic fields and disciplines. Resilience has become part of practice, policy, and business, ranging from poverty alleviation to political frameworks and business strategies to anticipate and respond to change and crisis, not only to survive, but also to evolve. Resilience is widely spread.

I was invited to contribute an article on this vibrant research field for the Oxford Research Encyclopedia of Environmental Science. The work with the article provided a welcoming opportunity to reflect on the state-of-the-art of resilience thinking 10 years after the review that Elinor Ostrom and Marco Janssen invited me to write for Global Environmental Change (Folke 2006). After submission to the Oxford Research Encyclopedia of Environmental Science, the contribution was shared with colleagues for comments and reflections. Several colleagues strongly recommended that it would be very valuable to have the Encyclopedia article also appearing as a journal article in openaccess format offering the work to a broader readership. I turned to Oxford University Press and asked about their views. They were very positive about having selected articles of the Oxford Research Encyclopedias, like this one, reprinted in scientific journals. My coeditor-in-Chief Lance Gunderson argued for Ecology and
Society as the natural venue, because resilience is one of the core concepts of the journal and persuasively encouraged me to proceed.

To make it clear, this invited article is a reproduction of the article "Resilience" published in the Oxford Research Encyclopedia of Environmental Science (Folke 2016). The only major difference is the new introduction and a reference list in line with Ecology and Society. Permission to republish the article in Ecology and Society has been granted by Oxford University Press USA.

The focus of the article is on resilience and the environment in relation to development and in particular on the evolution and spread of resilience thinking in this context (e.g., Walker and Salt 2006). The article opens with a section on "what is resilience?" that reports on early work on resilience and the environment, as well as the current definition of resilience in resilience thinking. The following section connects resilience with social-ecological systems in the context of sustainability science and complex adaptive systems raising issues like "resilience of people or planet in development?" The next section is about social-ecological resilience and the Anthropocene, which embraces issues on how to capture resilience, resilience in stewardship, and the significance of expecting the unexpected as well as enhancing resilience in general for the unknown and unknowable.

Resilience thinking emerged from the discovery, based on observation, that living systems have multiple basins of attraction (Holling 1973). It has developed into an approach for understanding complex adaptive systems and serves as a platform for interdisciplinary and transdisciplinary research with an emphasis on social-ecological systems (e.g., Levin et al. 2013). 
Social-ecological systems are intertwined systems of people and nature embedded in the biosphere, the thin, fragile layer of life around planet Earth (e.g., Folke et al. 2011). The biosphere connection is a central observation that has to be visible in work on resilience and social-ecological systems if sustainability is to be taken seriously.

\section{WHAT IS RESILIENCE?}

In some fields the term resilience has been used in a narrow sense to refer to the return rate to equilibrium upon a perturbation. Others tend to interpret resilience as bouncing-back after disturbance or recovery time, or recovery to what you were before in more general terms. In this way of looking at the world there is often an implicit focus on trying to resist change and control it to maintain stability. The resilience approach of resilience thinking is much richer. It deals with complex adaptive system dynamics and true uncertainty and how to learn to live with change and make use of it. Resilience thinking is the focus of this article.

In popular terms, resilience is having the capacity to persist in the face of change, to continue to develop with ever changing environments. Resilience thinking is about how periods of gradual changes interact with abrupt changes, and the capacity of people, communities, societies, cultures to adapt or even transform into new development pathways in the face of dynamic change. It is about how to navigate the journey in relation to diverse pathways, and thresholds and tipping points between them. In resilience thinking, adaptation refers to human actions that sustain development on current pathways, while transformation is about shifting development into other emergent pathways and even creating new ones.

Deliberate transformation involves breaking down the specific resilience of the old and building the resilience of the new (Folke et al. 2010). Specified resilience concerns resilience of what to what (Carpenter et al. 2001) and also for whom (Lebel et al. 2006, Robards et al. 2011, Brown 2014). General resilience is for the unknown and the unknowable (Kates and Clark 1996, Peterson et al. 2003a, Polasky et al. 2011a), for having the capacity to deal with complexity, uncertainty, and surprise (Walker et al. 2009a, Biggs et al. 2012a, Carpenter et al. 2012a). General resilience provides sources of memory, flexibility, options, and innovations for transformation and can help turn a crisis into an opportunity (e.g., Gunderson and Holling 2002, Nykvist and von Heland 2014).

\section{Early work on resilience and the environment}

Resilience as a concept in relation to the environment, or more specifically to ecosystems, was proposed by Holling (1973) as a way to understand the capacity of ecosystems to absorb change (reviewed by, e.g., Gunderson 2000, Desjardins et al. 2015) or more specifically, how to persist developing in the original state subject to disturbances and changing conditions (Holling 1973). Holling introduced resilience in the context of multiple stability domains or multiple basins of attraction in ecosystems, a radical idea at that time (Folke 2006). His discovery of multiple basins of attraction in ecosystem dynamics challenged the, at that time, dominant stable-equilibrium view of ecosystems. He investigated how ecosystems relate to random events and heterogeneity of temporal and spatial scales and defined resilience as persistence of relationships within a system, as a measure of the ability of systems to absorb changes of state variables, driving variables, and parameters, and still persist (Holling 1973).

The early days of resilience thinking draw on empirical observations of ecosystem dynamics often interpreted in mathematical models. Hence, inductive observations and empirical work led to the formulation of resilience as a feature of dynamic systems. Classic early work includes, for example, Ludwig et al. (1978), Walker et al. (1981), some of which are compiled in Gunderson et al. (2009). The pioneering interdisciplinary volume Sustainable Development of the Biosphere, edited by Clark and Munn (1986) included Holling's (1986) classic chapter developing the theoretical basis for resilience dynamics emerging from the comparison of the ecosystem studies. In that chapter, the adaptive cycle of system development was introduced.

The multibasins of attraction and resilience as the science of surprise became the theoretical foundation for the work with active adaptive management of ecosystems where Buzz Holling, Carl Walters, Bill Clark, and colleagues mobilized a series of studies of large scale ecosystems subject to management (Holling and Chambers 1973, Holling 1978, Walters and Hilborn 1978, Clark et al. 1979, Walters 1986, Walters and Holling 1990). The adaptive management process allowed for comparative analyses of the theoretical foundations of ecosystems behavior and ecosystems management. The conceptual underpinnings of adaptive management are simple; there will always be inherent uncertainty and unpredictability in the dynamics and behavior of complex systems, as a result of nonlinear interactions among components and emergence, yet management decisions must still be made, and whenever possible, learning should be incorporated into management (e.g. Allen et al. 2011). The resilience approach began early to influence work and discussions in fields outside ecology like anthropology, ecological economics, environmental psychology, human geography, the management literature, and others (reviewed in, e.g., Scoones 1999, Abel and Stepp 2003, Davidson-Hunt and Berkes 2003, Folke 2006).

The Beijer Institute of the Royal Swedish Academy of Sciences was restarted in 1991 with a focus on the interface of ecology and economy. In the diverse research programs of the Institute, resilience appeared and reappeared as a central feature for understanding complex system dynamics (e.g., Costanza et al. 1993). The volume Biodiversity Loss (Perrings et al. 1995) presented an ecological primer on functional diversity, regime shifts, and ecosystem services in an ecosystem resilience and crossscale context (Holling et al. 1995, see also Folke et al. 1996, Peterson et al. 1998, Nyström et al. 2000, Elmqvist et al. 2003, Lundberg and Moberg 2003, Hughes et al. 2007). Several papers as part of the Biodiversity Program (e.g., Perrings et al. 1992, Gadgil et al. 1993, Hammer et al. 1993, Walker 1993) and a recognized paper on economic growth (Arrow et al. 1995) incorporated resilience as a significant feature for human and environmental interactions (see also Levin et al. 1998). Holling and colleagues released the innovative book Barrier and Bridges to the Renewal of Ecosystems and Institutions in 1995 (Gunderson et al. 1995). The Beijer Institute program property rights and the performance of natural systems (Hanna et al. 1996) generated the Berkes and Folke (1998) volume Linking Social and Ecological 
Systems: Management Practices and Social Mechanisms for Building Resilience, one of the first volumes focusing on socialecological systems and resilience thinking (e.g., Ostrom 1999, Curtin and Parker 2014).

As a reflection of the significance of a resilience lens for understanding complex social-ecological systems, the research program The Resilience Network was initiated through a collaboration of the Beijer Institute (Mäler and Folke) and University of Florida (Holling and Gunderson), a program that engaged pioneering resilience thinkers and that triggered a lot of interesting and path-breaking work on resilience including the rich Panarchy volume (Gunderson and Holling 2002), a volume on the significance of nonlinear dynamics and regime shifts in economics, The Economics of Non-Convex Ecosystems (Dasgupta and Mäler 2004), and the Berkes, Folke, Colding 2003 book Navigating Social-Ecological Systems: Building Resilience for Complexity and Change emphasizing the challenge of governing dynamic interactions between gradual and abrupt changes in social-ecological systems. This book presented a major synthesis of resilience challenges for social-ecological systems (Folke et al. 2003).

The Resilience Network later developed into the Resilience Alliance (RA), founded in 1999, with a coherent group of researchers oriented toward common intellectual goals who worked together at the fringe of scientific understanding (Parker and Hackett 2012). The RA has contributed with insights on resilience in complex social-ecological systems (e.g., Peterson 2000, Janssen 2002, Walker et al. 2006, Norberg and Cumming 2008, Chapin et al. 2009), developed resilience thinking (e.g., Carpenter et al. 2001, Folke 2006, Walker and Salt 2006, Nelson et al. 2007, Quinlan et al. 2015), and also linked it to development agendas (e.g., Brown 2016). For example, Elinor Ostrom, engaged on the Beijer Institute Board and later on the Stockholm Resilience Centre Board, became part of the Resilience Alliance, inspired by resilience thinking and the work on social-ecological systems (Ostrom 1999, 2007, 2009). Ostrom's discussions at the Beijer Institute with Brian Walker and others on functional diversity and redundancy in ecosystem dynamics and regime shifts (e.g., Walker 1992, Peterson et al. 1998, Elmqvist et al. 2003) inspired her book on institutional diversity (Ostrom 2005).

Major syntheses on resilience and regime shifts in ecosystems were published (e.g., Scheffer et al. 2001, Carpenter 2003, Bellwood et al. 2004, Folke et al. 2004). Resilience work expanded from adaptively managing ecosystems (e.g., Gunderson and Pritchard 2002, Curtin and Parker 2014) to adaptively governing complex social-ecological systems (e.g., Folke et al. 2005, Armitage et al. 2007, 2009), bringing in the role of institutions, organizations, networks, and agency in this context (e.g., Adger 2000, Dietz et al. 2003, Olsson et al. 2004, Galaz 2005, Tompkins 2005, Crona and Bodin 2006, Lebel et al. 2006, Westley et al. 2006, Berkes 2009, Bodin and Crona 2009), social learning elements and knowledge systems (e.g., Berkes et al. 2000, Olsson and Folke 2001, Chapin et al. 2006, Fazey et al. 2007, Pahl-Wostl 2007, Forbes et al. 2009), ancient cultures (e.g., Redman and Kinzig 2003, Hegmon et al. 2008), and political and power dimensions of sustainability (e.g., Adger et al. 2005a, Gelcich et al. 2006, Michon 2011).
Now, the resilience concept has spread and this is not the place to review the large and expanding literature (e.g., Brand and Jax 2007, Janssen 2007, Brown and Westaway 2011, Xu and Marinova 2013, Baggio et al. 2015, Desjardins et al. 2015, Meerow and Newell 2015, Pu and Qiu 2016), close to an impossible task. But resilience is influencing the environmental sciences from agriculture to oceans as well as global environmental and climate change reflected in, e.g., Intergovernmental Panel on Climate Change (IPCC) reports (e.g., O'Brien et al. 2012) and in risk and disaster management (e.g., Berkes 2007, Tidball et al. 2010, McSweeney and Coomes 2011, Djalante et al. 2013). Resilience thinking is raised in the development literature and in diverse ontologies and epistemologies of the social sciences and the humanities (e.g., Hamel and Välikangas 2003, Redman 2005, Hegmon et al. 2008, Simmie and Martin 2010, Robards et al. 2011, Crépin et al. 2012, Plieninger and Bieling 2012, Ebbesson and Hey 2013, Hall and Lamont 2013, Lorenz 2013, Lyon and Parkins 2013, Barrett and Constas 2014, Chandler 2014, Tidball 2014, Bourbeau 2015, Hobman and Walker 2015, Marston 2015, Sjöstedt 2015, Weichselgartner and Kelman 2015) and with diverse reactions from excitement to those that oppose the approach for diverse reasons (reviewed by, e.g., Brown 2014 , Cretney 2014, Stone-Jovicich 2015).

After all, respect for pluralism (e.g., Norgaard 1989), epistemological agility (the capacity to work productively across knowledge domains; McWilliam 2009), and an open mind capable of moving out of and dynamically modifying one's preanalytic vision (e.g., Costanza 2001) are assets with the potential to augment collective understanding of complex social-ecological challenges. Attempts to integrate diverse perspectives or incorporate all dimensions into one unitary approach runs the risk of undermining the intellectual wealth and dialogues necessary to meet the challenges of the globally intertwined Anthropocene (e.g., Bousquet et al. 2015, Arora-Jonsson 2016). Resilience thinking serves as one useful lens among many to ask questions, learn, and improve understanding of social-ecological systems.

\section{Current definition of resilience thinking: integrating resilience, adaptability, transformability}

Resilience reflects the ability of people, communities, societies, and cultures to live and develop with change, with ever-changing environments. It is about cultivating the capacity to sustain development in the face of change, incremental and abrupt, expected and surprising (Folke 2006). The resilience approach emphasizes that social-ecological systems need to be managed and governed for flexibility and emergence rather than for maintaining stability (e.g., Peterson et al. 2003a, Carpenter et al. 2015a). Hence, resilience, as in focus here, is a dynamic concept concerned with navigating complexity, uncertainty, and change across levels and scales (e.g., Berkes et al. 2003, Cash et al. 2006, Cumming et al. 2013) on a human-dominated planet (e.g., Lubchenco 1998, Steffen et al. 2007).

Resilience is about persisting with change on the current path of development (stability domain or basin of attraction) adapting, improving, and innovating on that path. It is about having the capacity to continue to learn, self-organize, and develop in 
dynamic environments faced with true uncertainty and the unexpected, like steering a vessel in turbulent waters (e.g., Olsson et al. 2006).

But sometimes navigation leads to induced isolation and intensification of particular paths and to traps that are difficult to get out of (e.g., Holling and Meffe 1996, Sterner et al. 2006). The resilience of the system has become too robust and rigid (e.g., Allison and Hobbs 2004, Janssen and Scheffer 2004, Österblom et al. 2011, Steneck et al. 2011, Cumming et al. 2014). In such situations the challenge is to reduce or even break resilience of the current system to enable shifts away from the current pathway(s) into new ones, into alternative basins of attraction (Carpenter and Brock 2008, Walker et al. 2009a, Marshall et al. 2012, Enfors 2013). Sometimes those shifts may be smooth, other times revolutionary. As resilience declines, it takes progressively smaller disturbances to push the system into a different regime, or basin of attraction (Scheffer and Carpenter 2003). Such regime shifts are at the core of resilience thinking (e.g., Biggs et al. 2012b, Rocha et al. 2015).

Resilience is the capacity of a system to absorb disturbance and reorganize while undergoing change so as to still retain essentially the same function, structure, and feedbacks, and therefore identity, that is, the capacity to change in order to sustain identity; resilience is a dynamic concept focusing on how to persist with change (Walker et al. 2004, Folke et al. 2010), how to evolve with change. Adaptability refers to human actions that sustain development on current pathways. Adaptation is a process of deliberate change in anticipation or in reaction to external stimuli and stress (Nelson et al. 2007). Adaptation and adaptive capacity of people, communities, and societies are concepts in use in global environmental change in general and in climate change in particular (e.g., Smit and Wandel 2006, Engle 2011, Wise et al. 2014) with overlap with resilience thinking. The adaptability concept in resilience thinking captures the capacity of people in a social-ecological system to learn, combine experience and knowledge, innovate, and adjust responses and institutions to changing external drivers and internal processes. Adaptability has been defined as "the capacity of actors in a system to influence resilience" (Walker et al. 2004) and is about adapting within critical social-ecological thresholds. Adaptability is central to persistence. It helps turn changes and surprises into opportunities and, hence, is an important part of social-ecological resilience (Berkes et al. 2003, Nelson et al. 2007).

Transformability is about shifting development into new pathways and even creating novel ones. It is about having the ability to cross thresholds and move social-ecological systems into new basins of attractions, into new, emergent, and often unknown development trajectories (e.g., Walker et al. 2009a, Marshall et al. 2012). Such ability draws on sources of resilience from other levels and scales than the one in focus for the transformation of the existing system. Crises can open up space for transformations, for new ways of thinking and operating. Here, experiences can be revitalized, recombined for novelty, and help in navigating the arising transformative opportunities (e.g., Gunderson and Holling 2002, Folke et al. 2009). Transformability has been defined as "the capacity to create a fundamentally new system when ecological, economic, or social structures make the existing system untenable" (Walker et al. 2004, Folke et al. 2010).
Transformability and transformation trajectories are the subject of growing interest (e.g., Future Earth) and literature (e.g., Geels and Kemp 2006, Loorbach 2007, Chapin et al. 2010, Westley et al. 2011, Leach et al. 2012, O'Brien et al. 2012, Olsson et al. 2014). Some scholars see transformation as the consequence of societal collapse, and others see the capacity to actively transform as an essential property of long-lasting functioning social-ecological systems (Feola 2015). There are several different ways of approaching transformations (e.g., Fischer-Kowalski and Rotmans 2009, Pelling 2011, Kates et al. 2012, O’Brien 2012, Park et al. 2012, Moore et al. 2014). All concepts of transformation recognize that transformative processes are characterized by discontinuities, thresholds, or tipping points and do not generally proceed smoothly, and therefore these "cycles" or "phases" represent attempts to "make sense" (Westley et al. 2006) of the complex behavior of social-ecological systems rather than strictly defining features of transformation (Feola 2015).

The resilience approach to transformations is less about planning and controlling but more about preparing for opportunity or creating conditions of opportunity for navigating the transformations (Chapin et al. 2010). The resilience approach allows the new identity of the social-ecological system to emerge through interactions of individuals, communities, and societies, and through their interplay with the biosphere within and across scales (e.g., Cumming and Collier 2005, Sendzimir et al. 2007, Folke et al. 2010). It concerns encouraging arenas for safe-to-fail experimentation, facilitating different transformative experiments at small scales, and allowing cross-learning and new initiatives to emerge and spread across levels and scales, constrained only by avoiding trajectories undesirable from a sustainability perspective, especially those with known or suspected thresholds that challenge the capacity of the biosphere to sustain societal development and human well-being (Westley et al. 2011, Biggs et al. 2015). Enhancing resilience of the new stability domain is part of the transformation strategy (Chapin et al. 2010). The transformability insights of resilience thinking have largely emerged from case studies of social-ecological systems and human behavior in the real world (e.g., Olsson et al. 2004, 2006, 2008, Sendzimir et al. 2007, Gelcich et al. 2010, Marshall et al. 2012, Enfors 2013)

Resilience whether for adaptability or transformability operates and needs to be addressed across levels and scales (Gunderson and Holling 2002). Shifting pathways or basins of attractions at one level or scale does not take place in a vacuum. Any transformation draws on resilience from multiple scales and diverse sources of actors, organizations, institutions, recombining experience and knowledge, learning with change, turning crises into windows of opportunity, and allowing space for or even governing transformations for innovative pathways in tune with the resilience of the biosphere (Folke et al. 2003, 2005, 2010). Hence, in addition to emergence, resilience thinking emphasizes that humanity is embedded within the biosphere and that any attempt that takes sustainability seriously will require sustainability transformations with stewardship that operates in synergy with the biosphere foundation (Folke et al. 2011). Sustainability transformations seem to be necessary to achieve a just society that thrives within planetary boundaries and a biosphere resilient for humanity (Westley et al. 2011, O'Brien 2012). 


\section{RESILIENCE, COMPLEX ADAPTIVE SOCIAL- ECOLOGICAL SYSTEMS, AND SUSTAINABILITY SCIENCE}

To many, the resilience approach is a subset of sustainability science (e.g., Anderies et al. 2013, Takeuchi et al. 2014). Vulnerability research also has strong links to sustainability science (e.g., Turner et al. 2003a) and there are differences and similarities with resilience thinking (e.g., Miller et al. 2010, Turner 2010). Sustainability science is defined by the problems it addresses rather than by the disciplines it employs. A core focus of sustainability science is on transitions toward sustainability, including improving society's capacity to use the earth in ways that simultaneously meet the needs of a much larger but stabilizing human population, that sustain the life support systems of the planet, and that substantially reduce hunger and poverty (Clark 2007, Matson et al. 2016).

Berkes and Folke (1998) started to use the concept of socialecological systems as an integrated approach of humans-innature and related the concept to resilience. In this approach the social refers to the human dimension of people, communities, societies in its diverse facets (e.g., economic, political, institutional, cultural) and the ecological to the biosphere, the thin layer around planet Earth where there is life, human life included. They pointed out that in the social-ecological approach the "the delineation between social and natural systems is artificial and arbitrary" (Berkes and Folke 1998:4). In essence, the socialecological approach emphasizes that people, communities, economies, societies, cultures are embedded parts of the biosphere and shape ecosystems, from local to global scales, from the past to the future. At the same time people, communities, economies, societies, cultures are fundamentally dependent on the capacity of the biosphere to sustain human development (Folke et al. 2011). It represents a biosphere-based sustainability science with resilience thinking as a central ingredient.

Baggio et al. (2015) in their citation network analysis of resilience found that "the social-ecological systems field stands out as an emerging interdisciplinary arena where resilience can effectively act as a bridging concept and facilitate a discussion of dynamics of complex systems within varied contexts, informed by diverse perspectives, to provide potentially innovative theoretical and applied insights" (Baggio et al. 2015:8). Biggs et al. (2015) define resilience of a social-ecological system as the capacity of a socialecological system to sustain human well-being in the face of change, both by buffering shocks but also through adapting or transforming in response to change.

To understand the dynamics of intertwined social-ecological systems taking into account that the very nature of systems changes over time (e.g., Carpenter et al. 2015a), complex adaptive systems come increasingly into focus (e.g., Holland 1992, Levin 1998, Norberg and Cumming 2008). Social-ecological systems are complex adaptive systems. Complex adaptive systems possess critical thresholds, multiple drivers of change, and reciprocal feedbacks between social and ecological components (Levin et al. 2013).

\section{Resilience and complex adaptive social-ecological systems}

Many recurring environmental and natural resource challenges tend to be reinforced by the lack of recognition that ecosystems and the social systems that use and depend on them are intimately linked (Norgaard 1994, van der Leeuw and Aschan-Leygonie 2005, Reyers et al. 2013, Biggs et al. 2015). It is the feedback loops amongst them, as interdependent social-ecological systems, that determine their overall dynamics (Folke et al. 2002, 2010, Ostrom 2009, Bots et al. 2015, Carpenter et al. 2015a, Fischer et al. 2015). And in fact, they have been linked for a long time (e.g., Ellis 2015). Theoretical and empirical analyses show how intertwined socialecological systems are more than the sum of the ecological or the social or their combination, and provide new explanations to regime shifts and tipping points (e.g., Liu et al. 2007, Bodin and Tengö 2012, Lade et al. 2013, 2015, Hentati-Sundberg et al. 2015)

The resilience approach, as part of complex systems understanding (e.g., Holland 1995, Cillier 2008), emphasizes that systems of humans and nature exhibit nonlinear dynamics, thresholds, uncertainty, and surprise, and in particular how periods of gradual change interplay with periods of rapid change and how such dynamics interact across temporal and spatial scales (e.g., Gunderson and Holling 2002, Berkes et al. 2003). Complex systems have multiple attractors and there may be shifts from one attractor on a certain pathway to a new attractor and a contrasting pathway (stability domain or basin of attraction). Sharp shifts take place in ecosystems that stand out of the blur of fluctuations around trends and may have different causes (e.g., Scheffer and Carpenter 2003, Scheffer 2009). The likelihood of such shifts increases with loss of resilience (e.g., Scheffer et al. 2001). During the last decades it has become clear that human actions cause such shifts by altering resilience and disturbances (e.g., Folke et al. 2004, Biggs et al. 2012b, Schoon and Cox 2012) as is now illustrated from a growing set of examples of both ecosystems and social-ecological systems (Rocha et al. 2015) and even largescale reorganizations like historical shifts from foraging to farming (Ullaha et al. 2015). The Regime Shifts DataBase provides examples of different types of regime shifts that have been documented. The database focuses specifically on regime shifts that have large impacts on ecosystem services and therefore on human well-being. Hence, in resilience thinking, social and ecological systems are intertwined, exhibiting emergent properties and they can exist in qualitatively different states or basins of attraction.

Humans as agents in social-ecological systems shape emergent structures in different ways based on their cultural systems. Geertz (1973) presents culture as a historically transmitted pattern of meanings embodied in symbols, a system of inherited conceptions expressed in symbolic forms by means of which humans communicate, perpetuate, and develop their knowledge about and their attitudes toward life. Cultural systems consist of concepts linked in complicated ways that can form consistent world views, can contain inconsistencies, and may or may not accurately model the properties of a social-ecological system. Consequently, human influence will differ, depending on cultural systems (Trosper 2005). Deep cultural identities or cultural resilience may both constrain and be essential for adaptation or transformation (e.g., Walker et al. 2009a, Rotarangi and Stephenson 2014, von Heland and Folke 2014). The apparent stability and integrity of institutions and other social phenomena is not inherent, but an illusion created by the choice of a scale of observation that is shorter than the time over which the complex dynamics of the social-ecological system plays out (van der Leeuw and AschanLeygonie 2005). Humans as agents operate in diverse social and 
cultural contexts that are all an embedded part of the biosphere and that, consequently, will shape the biosphere in complex and different ways in continuous coevolution (e.g., Norgaard 1994).

In complex adaptive systems agents interact and connect with each other often in unpredictable and unplanned ways but from such interaction broader scale patterns with new properties emerge, which then feeds back on the system and influences the interactions of the agents (e.g., Lansing and Kremer 1993, Levin et al. 2013). Hence, the properties of complex adaptive systems change because of the interplay between the adaptive responses of the parts and the emergent properties of the whole that then feed back to the parts (e.g., Levin et al. 2013). The resilience of individuals, groups, and communities is tightly coupled to this interplay and the emergent properties of the whole.

Because complex adaptive systems portray radically disproportional causation (i.e., small causes do not always produce small effects) or "nonlinearity," they may depict periodic and chaotic dynamics, multiple basins of attraction, and potentially irreversible regime shifts (e.g., Biggs et al. 2009, 2012b, Norström et al. 2009). Multiple slow and fast drivers of change make it difficult to predict when such dramatic changes will occur and to pinpoint cause-and-effect mechanisms (e.g., Scheffer et al. 2012, Hughes et al. 2013). Living with such complexity and change is facilitated by collaborative and adaptive approaches to management and governance of the biosphere with decision making subject to high degrees of uncertainty and with continuous learning as an important feature (e.g., Ludwig et al. 2001, Folke et al. 2005).

\section{Resilience of people or planet in development?}

In resilience thinking and social-ecological systems research people are viewed as part of the planet, as part of the biosphere and consequently development issues, whether for poverty alleviation, reduced inequality, or diverse aspects of power, are embedded in a biosphere context. But it has to be stressed that even if a social-ecological system may seem to be on a sustainable biosphere pathway for human well-being, actions to improve resilience on that pathway may benefit resilience of some and undermine resilience and increase vulnerability of others (e.g., Lebel et al. 2006, Leach et al. 2010). In contrast, actions aimed at increasing resilience of individuals, communities, nations as the core focus may reinforce unsustainable pathways, undermine biosphere resilience and challenge sustainability (e.g., Arrow et al. 1995, Westley et al. 2011). Determining when resilience is on a desirable or undesirable path, and for whom, is an inherently value-laden, subjective and political question, a question that, if sustainability is in focus, needs to be connected to human wellbeing as part of the biosphere. From this perspective, sustainable development for humanity needs to be guided by approaches based on epistemologies and ontologies of development that appreciate the human-biosphere relationship.

Although on the table, issues of distribution, inequality, and diverse aspects of power and politics in their own right were not the core in the emergence of resilience thinking. Rather, they were incorporated as part of analyses of complex adaptive socialecological systems, reflected in the abundant resilience work on agency, actors, participation, diverse knowledge systems, learning, coproduction, adaptive management, social networks, collective action, institutions, stewardship, social-ecological innovation, transformation, and multilevel and adaptive governance of social-ecological systems. Issues of inequality and diverse aspects of power and politics in social-ecological systems and sustainability are explicitly addressed through collaboration across knowledge domains and in the continuous evolution of resilience thinking (e.g., Lebel et al. 2006, Crona and Bodin 2010, Raudsepp-Herne et al. 2010a, Smith and Stirling 2010, Michon 2011, Robards et al. 2011, Enfors 2013, Fischer et al. 2015, StoneJovicich 2015, Boonstra 2016). In this context, Brown (2016) argues that resilience can help understand and respond to the challenges of the contemporary age, challenges characterized by high uncertainty, globalized and interconnected systems, increasing disparities, and limited choices.

Resilience is increasingly having an impact on development research, from the individual, to community, to society as a whole. Development research with a resilience connection is becoming abundant, theoretically and empirically (e.g., Hall and Lamont 2013, Béné et al. 2016). For example, development resilience has been defined as "the capacity over time of a person, household or other aggregate unit to avoid poverty in the face of various stressors and in the wake of myriad shocks. If and only if that capacity is and remains high over time, then the unit is resilient" (Barrett and Constas 2014). The theory of development resilience approaches poverty dynamics of individuals in a way that makes the literature of economics and social science on poverty and poverty traps more explicit when considering issues of risk, dynamics, and appreciation of ecological feedback. This definition of resilience at the microscale puts the individual agents and their basic rights and aspirations for improved living conditions in focus.

There is work on poverty, adaptability, food security, social protection, adaptive capacity, and resilience of individuals, households, and groups in relation to ecosystem and environmental change in general, and climate change in particular (e.g., Kelly and Adger 2000, Berkes and Jolly 2001, Thomas and Twyman 2005, Andrew et al. 2007, Boyd et al. 2008, Davies et al. 2013, Marshall and Stokes 2014, Nayak et al. 2014, Cinner et al. 2015). For example, Béné et al. (2016) in their review of resilience in food security, nutrition, and development, employ the definition of resilience as used here (see above) in relation to shortterm humanitarian interventions, climate change projects, and long-term development programs. They argue that resilience results from the combination of absorptive capacity leading to persistence, adaptive capacity leading to incremental adjustments/changes and adaptation, and transformative capacity leading to transformational responses.

Community resilience has surfaced as a vibrant area (e.g., Amundsen 2012, Berkes and Ross 2013). For example, it has been found that communities can seize on the window of opportunity created by climate-induced shocks to generate sustained socialecological improvement, implying that management should foster local capacities for endogenous institutional change to enhance community resilience to climate shocks (McSweeney and Coomes 2011). Norris et al. (2008) argue that community resilience emerges from four primary sets of adaptive capacities, namely economic development, social capital, information and communication, and community competence and as a whole they help provide community capacity to deal with change, like disasters. Robards and Alessa (2004) note that Arctic 
communities have maintained their existence over time by their ability to recognize gradual or rapid changes and to adapt to those, rather than to any specific outcomes of a change. Resilience as a dynamic concept is reflected in the definition of community resilience as the existence, development, and engagement of community resources by community members to thrive in an environment characterized by change, uncertainty, unpredictability, and surprise and adapt and occasionally transform (Margis 2010). It is about planning for not having a plan, which requires flexibility, decision-making skills, and trusted sources of information that function in the face of unknowns (Norris et al. 2008). The cross-scale dimension of community and social resilience and in relation to globalization processes is gaining attention and striking the right balances between communities and their scalar interactions, and dependencies on global economic processes is key for social-ecological resilience (e.g., Wilson 2012, Scholes et al. 2013, Crona et al. 2015).

Brown and Westaway (2011) provide an excellent resilience review synthesizing knowledge on agency, adaptive capacity, and resilience across human development, well-being, and disasters literature to provide insights to support more integrated and human-centered approaches to understanding environmental change. They find first, that there has been a shift away from the notion that central concepts of resilience thinking-adaptive capacity, resilience, and well-being - can be objectively measured by a set of quantifiable indicators to a much more complex, nuanced view that understands them as comprising subjective, relational, as well as objective aspects. Second, there is a growing recognition that dynamic systems approaches, including ecological or social-ecological in its broadest sense, and crossscale perspectives are necessary. Third, in the human development, well-being, and disasters fields, there is a move away from deficit models to ideas about assets and capacities (Brown and Westaway 2011).

Brown (2016) in the recent book on resilience in development argues that a resilience-based approach to development might radically transform responses to climate change, to the dilemmas of managing ecosystems, and to rural and urban poverty in the developing world. She elaborates the notion of everyday forms of resilience as part of a new development agenda with three core components: resistance, rootedness, and resourcefulness. Resistance puts concerns for politics and power at the heart of resilience, how new spaces for change can be opened up and how positive transformation might be shaped and mobilized. Rootedness is about locating culture and place, both as biophysical environment and context and as identity and attachment, whilst also working at and across multiple scales. Resourcefulness concerns capacities, types of knowledge, innovation, and learning and how resources can be accessed and used in response to change.

In a classic paper, Adger (2000) compares social and ecological resilience and defines social resilience as the ability of groups or communities to cope with external stresses and disturbances as a result of social, institutional, political, and environmental change. Hall and Lamont (2013) present a systems-oriented definition of social resilience that, very much like resilience thinking, emphasizes adaptation or transformation over return to an earlier state. They are interested, in general terms, in the understanding of how individuals, communities, and societies secure their wellbeing in the face of its challenges, how well-being is secured by groups of people more or less bound together in an organization, class, group, community, or country. More specifically, they see social resilience in dynamic terms as the achievement of well-being even when that entails significant modifications to behavior or to the social frameworks that structure and give meaning to behavior. Well-being in this context refers broadly to physical and psychological health, material sustenance, and the sense of dignity and belonging that comes with being a recognized member of the community or society. Hence, in focus is the capacity of individuals or groups to secure favorable outcomes (material, symbolic, emotional) under new circumstances and when necessary by new means. Consequently, social resilience is used to denote an outcome in which members of a group sustain their well-being in the face of challenges to it (Hall and Lamont 2013).

The additional argument from resilience thinking is that well-being of individuals, communities, and societies is tightly coupled to the capacity of the biosphere to sustain it. This is an obvious fact in a situation when the scale, connectivity, spread, and speed of human actions shape the dynamics of the biosphere and the earth system as a whole (e.g., Turner et al. 1990, Steffen et al. 2007, 2015, Folke et al. 2011).

\section{RESILIENCE AND THE ANTHROPOCENE}

The scale of human actions and the speed, spread, and connectivity of globalization create new complex dynamics across levels and domains that play out in new ways (e.g., Young et al. 2006, Walker et al. 2009b, Biggs et al. 2011, Homer-Dixon et al. 2015). Interconnections of humans in a globalized society can propagate and cascade across countries and regions (e.g., Adger et al. 2009, Galaz et al. 2011, Liu et al. 2013, Eriksson et al. 2015, Österblom et al. 2015), shaping landscapes, seascapes, the well-being of people and social-ecological systems worldwide (e.g., Holling 1995, Hughes et al. 2003, Berkes et al. 2006, Fairhead et al. 2012, Galaz 2014, Lazarus 2014, Merrie et al. 2014. Keys et al. 2016). These interactions and feedbacks are not just global but cross-scale (e.g., Deutsch et al. 2007, Lambin and Meyfroidt 2011, Thyresson et al. 2011, Crona et al. 2015, Galaz et al. 2015) and their speed may even make the global operate faster than the local. It implies that studies and action of the local should not only focus on endogenous relations, but also account for and prepare for living and collaborating with influences from other levels, be it political decisions, economic drivers, transnational companies, migration policies, altered rainfall patterns, or climate change (e.g., Walker et al. 2009b, Folke et al. 2011, Rockström et al. 2014a). Some of those may be slow creeping influences, others abrupt and surprising (e.g., Hansen et al. 2012, Hughes et al. 2013, Homer-Dixon et al. 2015). It is a truly intertwined social-ecological planet we are living on.

The great acceleration of the human dimension on earth, in terms of people and activities, and diverse reasons behind it from the discovery of fossil fuels to power dynamics between nations and regions, has placed humanity in new terrain as a major force in shaping biosphere processes. This scale increase in relation to the life-supporting biosphere (e.g., Boulding 1966, Odum 1989, Daily and Ehrlich 1992, Arrow et al. 1995) has moved humanity into a proposed new geological era, the Antropocene, the age of man (Steffen et al. 2007, Brondizio et al. 2016). Resilience and regime 
shifts are part of the challenges humanity is facing in the Anthropocene, from regional tipping points (e.g., Lenton et al. 2008, Österblom and Folke 2015) to possible shifts at planetary scales (e.g., Steffen et al. 2011, Barnosky et al. 2012) and assessments of dynamic planetary boundaries in this context (Rockström et al. 2009, Steffen et al. 2015). It has been suggested that to sustain the planet in a Holocene-like state (the geological era of the last 11 thousand years of favorable condition for development of human civilizations), transformations at local and regional scales will be needed (e.g., Steffen et al. 2015). In other words, to sustain resilience of favorable biosphere conditions for humanity as a whole, there will have to be transformations toward new ways of development, not just incremental tweaking of business as usual on current development pathways (e.g., Folke et al. 2010, Westley et al. 2011). Views on good or bad pathways of transformations differ and often depend on values and political positions on issues like globalization, power inequalities, and distribution conflicts of development, uneven environmental degradation included (e.g., Hornborg et al. 2007). A resilience approach would emphasize flexibility and opportunity of diverse pathways and keeping options open to be able to shift between those, in a manner that remains within the safe operating space of the biosphere, and with prosperity and abundance for humans in collaboration with biosphere resilience.

\section{Capturing resilience}

Resilience as an approach for analyzing, understanding, and managing change in social-ecological systems is different from resilience as a property of a social-ecological system (e.g., Nelson et al. 2007, Biggs et al. 2015). Resilience as a system property is, as discussed earlier, the capacity of a specific social-ecological system to continually self-organize and adapt in the face of ongoing change in a way that sustains the system in a certain stability domain or development path. When analyzing resilience as a system property in relation to regime shifts it is useful to consider resilience of what to what (Carpenter et al. 2001). Biggs et al. (2015) see resilience as the capacity of a social-ecological system to sustain human well-being in the face of change, by persisting and adapting or transforming in response to change. A central challenge in this context is the capacity of social-ecological systems to continue providing key ecosystem services that underpin human well-being in the face of unexpected shocks as well as gradual, ongoing change (e.g., Bennett et al. 2009, Carpenter et al. 2009a, Biggs et al. 2015).

How can resilience as a property be captured? There is a search for metrics and indicators of resilience, not an easy task because social-ecological systems are complex adaptive systems, with moving targets continuously developing and evolving. It is important to avoid the trap of developing metrics of what is easy to measure rather than what is important (Carpenter et al. 2009b). Developing a set of indicators of resilience as a system property may block the deeper understanding of system dynamics needed to apply resilience thinking and navigate a turbulent world (e.g., Quinlan et al. 2015). Therefore, resilience as a system property should not be reduced to a simple metric, but different types of metrics and indicators need to be used and combined to capture facets of resilience and help guide management and governance. A snapshot of approaches is presented below.
In recent years progress has been made in understanding signals of regime shifts and critical transitions. Resilience research has clarified how phenomena such as flickering, critical slowing down, increased autocorrelation, decreasing recovery rates, and increased variance can serve as "early warnings" of loss of resilience and regime shifts in nature, from ecosystems to the dynamics of the planet as a whole (e.g., Dakos et al. 2008, Scheffer et al. 2012), and how such signals relate to management, human behavior, and the safe-operating spaces of ecosystem regimes (e.g., Biggs et al. 2009, Crépin et al. 2012, Scheffer et al. 2015, Schill et al. 2015). The safe-operating space was proposed in relation to zones of uncertainty with potential thresholds of critical processes at the global level, or planetary boundaries, where loss of resilience and regime shifts may challenge essential favorable conditions for human life on Earth (Rockström et al. 2009).

Several studies aim at developing resilience indicators in relation to regime shifts in diverse ecosystems, often with a focus on the interplay of fast and slow variables and feedback management (e.g., Carpenter et al. 2001, Nyström et al. 2008, 2012, Graham et al. 2013, Jouffray et al. 2015) and how those are connected in dynamic landscapes and seascapes and across scales, i.e., spatial resilience (e.g., Nyström and Folke 2001, Bengtsson et al. 2003, Cumming 2011, Sundstrom et al. 2014) or with broader processes like rainfall patterns (Gordon et al. 2008, Keys et al. 2012) or fisheries and global seabird populations (Cury et al. 2011). There are efforts aimed at capturing resilience in economic terms and models in relation to regime shifts (e.g., Mäler and Li 2010, Walker et al. 2010, Polasky et al. 2011a, Crépin et al. 2012, de Zeeuw 2014, Richter and Dakos 2015).

Others are developing metrics of change in ecosystem services and natural capital in relation to social-ecological systems and human well-being and with connections to resilience (e.g., Raudsepp-Hearne et al. 2010b, Guerry et al. 2015). Some focus on measuring resilience for whom at the individual level and often in relation to poverty (e.g., Barrett and Constas 2014) or on understanding how communities can transform out of poverty traps (e.g., Enfors 2013) or on how to break resilience of one development path and transform to another and build resilience of that path (e.g., Moore et al. 2014). Crisis turning into windows of opportunity and aligning actors and networks across multilayers of governance at critical moments seem to be of significance in such social-ecological regime shifts (e.g., Olsson et al. 2004, Chapin et al. 2010, Schultz et al. 2015).

There are those who concentrate on adaptation and adaptive capacity in relation to change with links to resilience thinking (e.g., Wise et al. 2014) and there have been attempts to identify surrogates for resilience (e.g., Carpenter et al. 2005) as well as sources of resilience (e.g., Adger et al. 2005b, 2011, Goulden et al. 2013). The latter concept is closely related to the theoretical concept of "remember" for reorganization (Gunderson and Holling 2002), which has inspired studies on social-ecological memory as critical for resilience building as well as the role of biocultural refugia as pockets of social-ecological memory in times of change (Barthel et al. 2010, 2013, Barthel and Isendahl 2013). The role of memory and sources of resilience are addressed in work on cultural landscapes and with links to senseof-place and deep identities as resilience features in adaptations 
and transformations (e.g., Turner et al. 2003b, Crane 2010, Tidball et al. 2010, Plieninger and Bieling 2012, Adger et al. 2013, Tidball and Stedman 2013, Lyon 2014, Fernández-Giménez 2015). There is work on cultural resilience, often in relation to indigenous groups and cultures subject to change, emphasizing elements (e.g., resilience pivots, ancestral contracts) of a social-ecological system that endure despite adaptation or even transformation of other elements and in doing so support the persistence of the system's distinctive identity (e.g., Forbes 2013, Rotarangi and Stephenson 2014, von Heland and Folke 2014).

Another critical feature concerns the role of functional biodiversity and functional groups of species in ecosystem resilience and regime shifts (e.g., Peterson et al. 1998, Walker et al. 1999, Bellwood et al. 2004, Folke et al. 2004, Hughes et al. 2007) with parallels to the role of agency and diverse actors and actor groups in socialecological system dynamics and their adaptations and transformations (e.g., Folke et al. 2003, 2005, Westley et al. 2013). Functional diversity and social actor strategies are increasingly linked (e.g., Diaz et al. 2011). A critical concept for resilience management in this context is response diversity, defined as the diversity of responses to environmental change among species contributing to the same ecosystem function (Elmqvist et al. 2003). Response diversity has been found to be particularly important for renewal and reorganization in ecosystems following change (e.g., Hughes et al. 2007, Winfree and Kremen 2009, Jansson and Polasky 2010, Laliberte et al. 2010). The concept is gaining interest in research on social-ecological systems including livelihood options across multiple levels (e.g., Leslie and McCabe 2013) and in governance and management of urban landscapes and ecosystem services (e.g., Andersson et al. 2007, Colding 2007).

There will always be tension between the degree of simplification that measurement and metrics demand and the point at which these make the system understanding fragmented and their implementation meaningful (Quinlan et al. 2015). Resilience assessments aim at a deep understanding of social-ecological system dynamics, recognizing that resilience is a dynamic property shaped by many different processes of interacting fast and slow variables, including the larger context and cross-scale dynamics in which the social-ecological system is embedded (e.g., Scholes et al. 2013) as well as unintentional changes of unforeseen dynamics (e.g., Quinlan et al. 2015). Building on a theoretical foundation and case study history, resilience assessments offer guidance toward understanding social-ecological dynamics of a given place and time with the objective to inform management (e.g., Walker and Salt 2012, Mitchell et al. 2014). The practice of resilience assessments has illustrated the value of a shared process of learning and understanding complex social-ecological systems dynamics (Quinlan et al. 2015). Resilience assessments have been tested and applied in a number of settings like catchment and mountain management in Australia and the USA, municipalities and urban areas in Canada and Sweden, or pasture management in Afghanistan (e.g., Walker et al. 2009a, Haider et al. 2012, Nemec et al. 2013, Liu 2014, Lockwood et al. 2014, Sellberg et al. 2015). An updated framework based on the Resilience Alliance's Workbook for practitioners (Resilience Alliance 2010), originally developed by Lance Gunderson, Ann Kinzig, Allyson Quinlan, and Brian Walker, combines the focus on understanding complex adaptive social-ecological systems in the new Anthropocene context with guiding the identification and use of indicators to measure and monitor over time (O'Connell et al. 2015).

Resilience and stewardship of social-ecological systems: from the local to the global

Urbanization is a major driver of the Anthropocene (e.g., Seto et al. 2012) with well over half of the human population currently living in urban areas. There is a tendency to become mentally disconnected from the biosphere in urban settings (e.g., GómezBaggethun and Barton 2013). There is lot of work on urban resilience (e.g., Pickett et al. 2004, Andersson 2006, Leichenco 2011, Elmqvist et al. 2013, Marcus and Colding 2014, Pu and Qiu 2016). Green spaces and their stewards and stewardship is an exciting area of resilience research in urban social-ecological systems (e.g., Colding et al. 2006, Andersson et al. 2007, Colding 2007, Ernstson et al. 2008, Wilkinson et al. 2010, Wilkinson 2012, Colding and Barthel 2013, Connolly et al. 2014) often with emphasis on how to reconnect people in cities and urban development to the biosphere and essential ecosystem services in relation to resilience (e.g., Gómez-Baggethun and Barton 2013, Jansson 2013, Andersson et al. 2014, McPhearson et al. 2015).

In the globally intertwined social-ecological system everyone is in everyone else's backyard, and cities both shape and are dependent on huge areas across the planet of ecosystems support (e.g., Folke et al. 1997, Grimm et al. 2008) for water, food, and other ecosystem services (e.g., Bennett et al. 2014, Rist et al. 2014, Rockström et al. 2014b, Troell et al. 2014). It will be in the selfinterest of urban dwellers in the Anthropocene to create incentives for stewardship of their supporting ecosystems, or socialecological systems often far away from city borders that secure the basis of city life.

The stewardship challenge is of central focus in resilience thinking (e.g., Folke et al. 2003, Chapin et al. 2009; Fig. 1) from early work on adaptive management to regime shifts and adaptive governance of social-ecological systems and ecosystem services. Ecosystem services are a key emergent outcome of socialecological interactions (e.g., Reyers et al. 2013, von Heland and Folke 2014). But, the stewardship challenge makes clear that, although people's management is critical, it is not sufficient to focus only on the human dimension if sustainability is central, because sustainability requires governance systems and development practices in tune with biosphere capacity (e.g., Folke et al. 2011, Guerry et al. 2015). Therefore, ecological knowledge and understanding of ecosystem processes and dynamics, of the natural capital, and the social-ecological interplay of such processes and dynamics is a prerequisite in this context (e.g. Berkes and Folke 1998, Berkes et al. 2003). Skill sets for stewardship of natural capital range from abilities of experimenting, learning, and gaining ecological knowledge and experience on the ground (e.g., Olsson et al. 2004, King 2008, Chapin et al. 2009) to capturing and accounting for broader scales biophysical processes like rainfall patterns or climate dynamics (e.g., Keys et al. 2012, Rockström et al. 2014a) in the governance and management of social-ecological systems. Supported by proper institutions and incentives such skills help build identity, meaning, pride, and dignity in being a steward of the ecological foundation for human well-being in collaboration with the biosphere. 
Fig. 1. Examples of stewardship strategies for dealing with uncertainty and change and strategies to transform from unsustainable social-ecological pathways to potentially more favorable ones (modified from Chapin et al. 2010).

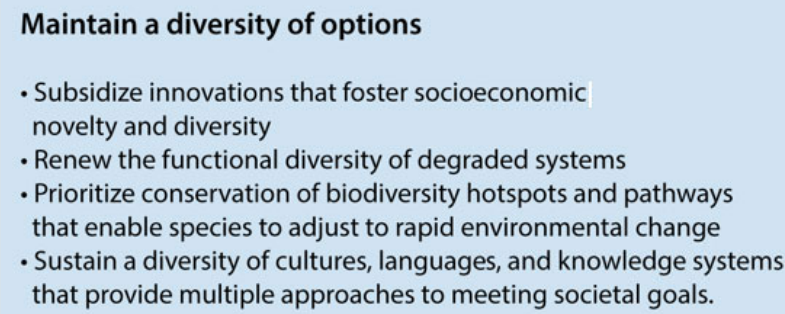

\section{Enhance social learning to facilitate adaptation}

- Broaden the problem defintion and knowledge coproduction by engaging multiple disciplinary perspectives and knowledge systems - Use scenarios and simulations to explore consequences of alternative policy options

- Develop transparent information systems and mapping tools that contribute to developing trust among decision makers and stakeholders, and build support for action

- Test understanding through comparative analysis, experimentation, and adaptive management

- Exercise extreme caution in experiments that perturb a system larger than the jurisdiction of management

\section{Adapt governance to implement potential solutions}

- Provide an environment for leadership and respect to develop - Foster social networking that builds trust and bridges communication and accountability among existing organizations

- Enable sufficient overlap in responsibility among organizations to allow redundancy in policy implementation

\section{Preparing for transformation}

- Engage stakeholders to identify dysfunctional states and raise awareness of problems

- Identity thresholds, plausible alternative states, pathways, and triggers - Identify the barriers to change, potential change agents, and strategies to overcome barriers

\section{Navigating the transformation}

- Identify potential crises and use them as opportunities to initiate change

- Maintain flexible strategies and transparency

- Foster institutions that facilitate cross-scale and cross-organizational interactions and stakeholder participation

\section{Building resilience of the new regime}

- Create incentives and foster values for stewardship in the new context - Initiate and mobilize social networks of key individuals for problem solving

- Foster interactions and support of decision makers at other levels
Work on distribution, equality, fairness, justice, power are of major significance in the resilience and stewardship context, but seldom the core focus in their own right. They enter resilience thinking as significant features of understanding and governing social-ecological dynamics for biosphere stewardship, human well-being, and sustainability (e.g., Lebel et al. 2006, Robards et al. 2011, Fischer et al. 2015).

The challenge of biosphere stewardship and resilience was raised in the Millennium Ecosystem Assessment and through the engagement of resilience-oriented scholars in the development of the assessment, especially in the case studies of the subglobal assessment as well as the scenarios work (e.g., Capistrano et al. 2006, Reid et al. 2006). Here, the role of people as part of ecosystem dynamics and stewardship of dynamic landscapes and seascapes and their ecosystem services were in the forefront as well as the challenge of bringing in diverse knowledge systems as part of stewardship and governance across institutions at multiple levels (Carpenter et al. 2009a).

There is a lot of work on management of ecosystem resilience for ecosystem services (e.g., Moberg and Folke 1999, Scheffer et al. 2015) with adaptive management as a way of experimenting, learning, and developing understanding for stewardship (e.g., Allen et al. 2011). The literature on adaptive comanagement of ecosystem and complex social-ecological systems is also rich (e.g., Armitage et al. 2007, 2009, Berkes 2009, Cinner et al. 2012). There is resilience work on the role of indigenous and local knowledge systems as experienced-based knowledge for ecosystem management of social-ecological systems including shocks (e.g., Berkes et al. 2000, Forbes et al. 2009, Gómez-Baggethun et al. 2013, Rumbach and Foley 2014) and how to connect diverse knowledge systems, the role of coproduction of knowledge, and collaborative learning among communities and stakeholders and their significance in stewardship of ecosystem services (e.g., Fazey et al. 2007, Raymond et al. 2010, Schultz and Lundholm 2010, Bohensky and Maru 2011, Mathevet et al. 2011, Goldstein 2012, Boyd et al. 2013, Tengö et al. 2014, Daw et al. 2015, Reyers et al. 2015). Socialecological inventories have been used to set such processes in motion (e.g., Schultz et al. 2007, Baird et al. 2014) and the concept of ecological solidarity highlights the intertwined interplay of social-ecological systems (Mathevet et al. 2010, 2016) .

Resilience work has studied institutions and governance structures that allow for ecosystem-based management in some detail and 
has focused especially on the emergence of flexible governance arrangements that have shifted and transformed human activities toward adaptive governance of social-ecological systems (e.g., Folke et al. 2005, Huitema et al. 2009, Chaffin et al. 2014, Karpouzoglou et al. 2016). This work has been particularly well developed with regard to the stewardship of landscapes and seascapes (e.g., Olsson et al. 2004, 2006, 2008, Gelcich et al. 2010, Cosens and Williams 2012). Several studies illustrate the role of institutional entrepreneurs in this context (e.g., Folke et al. 2005, Ernstson et al. 2010, Meijerink and Huitema 2010, Rosen and Olsson 2013, Westley et al. 2013, Merrie and Olsson 2014). In these situations actors start interacting and connecting with each other, often in unpredictable and unplanned ways, and from such interactions broader scale patterns with new properties emerge, which than feed back on the social-ecological system and influence the actors and their interactions (Levin et al. 2013). Such a dynamic interplay of actors, social networks, bridging organizations, and diverse and multilevel institutions, continuously learning with change, are found to be significant features of social-ecological system dynamics, often emerging in relation to crisis (perceived or real) as well as the opening of windows-of-opportunity for change toward stewardship of ecosystem services (e.g., Olsson et al. 2004, 2008, Hahn et al. 2006, Pahl-Wostl et al. 2007, Bodin and Crona 2009, Crona and Parker 2012, Rathwell and Peterson 2012, Österblom and Folke 2013, Schultz et al. 2015). Such "adaptive waves" of moving up scales of social-ecological systems occur both inadvertently and deliberately in response to both rapid and gradual changes and may lead to increased resilience on a higher governance scale (e.g., Olsson et al. 2007, Luthe and Wyss 2015).

However, restructuring current institutions and governance systems for resilience is no small task and the challenge in relation to social-ecological systems and resilience is subject to a growing literature (e.g., Dietz et al. 2003, Young 2010, 2011, Schlüter and Herrfardt-Pähle 2011, Sjöstedt 2015). Such restructuring raises issues of representative democracy, accountability, and legitimacy in governance (e.g., Hahn 2011, Cosens 2013). There is also the problem of fit between institutions, governance, and socialecological systems (e.g., Galaz et al. 2008, Ekstrom and Young 2009, Treml et al. 2015) and how institutions and governance systems can handle change and stability simultaneously (e.g., Duit et al. 2010, Voß and Bornemann 2011, Green et al. 2013) including cascading changes of an intertwined world (e.g., Galaz et al. 2011). Global governance challenges are raised in relation to planetary boundaries and stewardship (e.g., Biermann et al. 2012, Galaz et al. 2012a) and the emergence of new forms of institutions for governance of the biosphere (e.g., Galaz et al. 2012b).

There is also work on resilience in relation to legal structures, principles, and processes (e.g., Garmestani et al. 2013), as well as core concepts of the rule of law (e.g., Ebbesson 2010) and to the making of normative choices of public interest, public and private responsibilities, and individual rights including equality before the law and nondiscrimination (e.g., Ebbesson and Hey 2013). West and Schultz (2015) conclude that the European Court of Human Rights constitutes an important site of learning for governance of social-ecological systems, because it situates knowledge and experience of environmental change in the context of discussions about the relative rights, duties, and responsibilities of social actors, facilitating the mutually adaptive evolution of truth and justice across scales. Work on new forms of social contracts, emphasizing the dynamics, links, and complexity of socialecological systems is also part of the resilience discourse (O'Brien et al. 2009). As stated by Cosens (2013) the recognition of the complexity in the social-ecological system, coupled with a growing realization of the complete dependence of the human race on the ability of the ecological system to serve it, requires reform of the administrative state to allow society to responsibly respond to the challenge of managing human interaction with ecosystems.

Scenario planning is a forward looking approach aimed at articulating multiple alternative futures in a way that spans a key set of critical uncertainties, using qualitative and quantitative methods and data (e.g., Peterson et al. 2003b, Swart et al. 2004, Carpenter et al. 2006) and engaging diverse stakeholder in participatory processes for stewardship of social-ecological systems subject to change (e.g., Enfors et al. 2008, Plieninger et al. 2013, Carpenter et al. 2015b, Oteros-Rozas et al. 2015). Scenario work is an important part of the Future Earth Programme on Ecosystem Change and Society (PECS), a program with a strong focus on social-ecological systems, resilience, and stewardship of ecosystem services in dynamic landscapes and seascapes, operating in the context of the challenges of the Anthropocene (Carpenter et al. 2012b, Fischer et al 2015).

\section{Expect the unexpected}

In their paper "Environmental surprise: expecting the unexpected?" Kates and Clark (1996) make clear that in a complex and intertwined world surprise is to be expected. Resilience thinking has been characterized as the science of surprise. Surprise-when perceived reality departs qualitatively from expectation-is strongly shaped by underlying metaphors, models, and belief systems (Holling 1986).

Surprise is not just about shocks and extreme events but also about slower changing and less visible dynamics (e.g., Gunderson 2001). We are not always aware of the sands shifting beneath our feet as events change the character of the times in diffuse ways (Hall and Lamont 2013). Resilience thinking is about the interplay of incremental and abrupt change, of slow and fast variables in complex adaptive systems and how it plays out in uncertain, surprising, and often unpredictable ways (e.g., Gunderson and Holling 2002, Carpenter et al. 2009b). Resilience thinking is about true uncertainty and unknown unknowns and not just about probabilities around risk and uncertainty (Carpenter et al. 2006, 2009b, Polasky et al. 2011b).

As suggested by Holling (1986) contemporary challenges of the globally intertwined social-ecological systems are indeed system challenges, complex, unpredictable, nonlinear, with discontinuous behavior in space and time and where causes, at times simple, are always multiple. The cross-scale challenges are a reflection of decadal to centurial accumulation of human influences on air and oceans and transformations of landscapes causing sudden changes in fast environmental variables and affecting the health of people, the vitality of societies, and the essential life-support functions of the biosphere (e.g., Clark and Munn 1986, Gunderson et al. 1995). Indeed, the complex interplay of human actions shaping biosphere capacity has placed humanity in a novel situation of interactions of social-ecological systems across scales that are expressed in new, intertwined, and often turbulent and 
surprising ways (e.g., Walker et al. 2009b, Galaz et al. 2011, Biggs et al. 2011, Homer-Dixon et al. 2015, Steffen et al. 2015) affecting people and places in disparate ways. The situation presents major challenges but also opportunities for adaptation and transformation (e.g., Adger et al. 2011, Westley et al. 2011, Biermann et al. 2012, Galaz et al. 2012a,b, Hill and Engle 2013).

Solutions that focus on knowledge of small parts or that assume constancy or stability of fundamental relationships tend to be pathological producing policy and science with a sense of certainty leading to rigid and unseeing institutions and increasingly vulnerable social-ecological systems (Holling 1986, Gunderson et al. 1995, Holling and Meffe 1996). It may even be possible that recent advances and widespread availability of information may make people overconfident about the ability to anticipate and deal with surprise, and thereby making people more vulnerable to it (Kates and Clark 1996). The challenge is to anticipate change and surprise in a manner that does not lead to lock-in and loss of future options (e.g., Costanza et al. 2000, Berkes et al. 2003, Boyd et al. 2015).

Managing for resilience enhances the likelihood of sustaining development in a rapidly changing world where surprise is likely (e.g., Folke 2006, Carpenter et al. 2009b, Chapin et al. 2009). When transformation is inevitable, resilient social-ecological systems contain the components needed for renewal and reorganization, reconnecting development to the biosphere for human well-being and sustainability (e.g., Folke et al. 2002, Boyd and Folke 2012, Biggs et al. 2015).

Resilience-building management of the Anthropocene is flexible and open to learning. It attends to slowly changing, fundamental variables that create memory, legacy, diversity, and the capacity to innovate in both social and ecological components of the system. It also conserves, builds experience, and nurtures the diverse elements that are necessary to reorganize and adapt to novel, unexpected, and transformative circumstances. Thus, it increases the range of surprises with which a social-ecological system can cope (Folke et al. 2002) and may even serve to open windows-of-opportunity for societies to increase capacity to govern social-ecological change over the long term (e.g., Kates and Clark 1996, Luthe and Wyss 2015).

Often, resilience is applied to challenges relating to particular aspects of a social-ecological system that might arise from a particular set of sources or shocks, referred to as specified resilience (Walker et al. 2009a). Specified resilience arises in response to the question "resilience of what to what?" (Carpenter et al. 2001) and for "whom" (e.g., Lebel et al. 2006). Becoming too focused on specified resilience to increase resilience of particular parts or dimensions of a social-ecological system to specific disturbances may cause the system to lose resilience in other ways. This observation is critical for, e.g., disaster management or policies aimed at poverty alleviation (e.g., Berkes 2007, Djalante et al. 2013). For example, the Pumpa socialecological system of rice-paddy irrigation in Nepal developed into a socially well-tuned institution for dealing with specific fluctuations of climate and hydrology, but in the process the governance structure for water management created vulnerability to long-term changes in climate and institutional arrangements (Cifdaloz et al. 2010).
In fact, it seem like governance and management aimed at reducing variance in flows of ecosystem services will lead to loss of resilience in social-ecological systems to changing conditions (Carpenter et al. 2015a). Hence, there are trade-offs between resilience of a social-ecological system to a small set of known kinds of disturbance versus the vast universe of unknown novel shocks (e.g., Carpenter et al. 2009b). Specified resilience approaches may be narrowing options for dealing with novel shocks and even increasing the likelihood of new kinds of instability (Carpenter et al. 2015a). It seems like systems that become very robust to frequent kinds of disturbance necessarily become fragile in relation to infrequent kinds (e.g., Folke et al. 2010, Anderies 2015).

\section{Enhancing resilience in general}

General resilience is a more broad-spectrum type of resilience for building capacity of social-ecological systems to adapt or transform in response to the unknown. It is about resilience to all kinds of shocks, including extreme, novel, and noncomputable ones (e.g., Carpenter et al. 2009b). Among conditions that enable general resilience are diversity, modularity, openness, reserves, feedbacks, nestedness, monitoring, leadership, and trust (Carpenter et al. 2012a). General resilience is about having the capacity to deal with ongoing diffuse gradual change, with true uncertainty and surprise. General resilience envisions a central role in buying insurance against surprises generated by complex intertwined social-ecological systems of the Anthropocene. But, as a public good it has a cost. How much general resilience is needed, in what dimensions, and how can long-term practices be woven into actions that also meet the immediate needs of people and ecosystems?

Based on empirical work and case studies, Folke et al. (2003) proposed four key features of general resilience-building for adaptive capacity, features that interact across temporal and spatial scales and that seem of significance for dealing with dynamics in social-ecological systems:

- learning to live with change and uncertainty;

- nurturing diversity for reorganization and renewal;

- combining different types of knowledge for learning; and

- creating opportunity for self-organization toward socialecological sustainability.

The first emphasizes the significance of accepting uncertainty and surprise, taking advantage of change and crisis, and having the capacity of turning change into opportunity for social-ecological development in tune with the biosphere. The second illuminates the importance of nurturing diversity for social-ecological resilience, recognizing that diversity is more than insurance against uncertainty and surprise. It also provides the bundle of components, and their history, that makes development and innovation following disturbance and crisis possible, components that are embedded in the social-ecological memory. The third is about the significance of peoples' knowledge, experience, and understanding about ecosystem dynamics and their inclusion in management practice and institutions. The fourth brings these issues together in the context of self-organization, scale, governance, and external drivers, stressing the significance of the dynamic interplay between diversity and disturbance (Folke et al. 2003). 
Biggs et al. $(2012 b$, 2015) have identified a set of seven generic and policy-relevant principles for enhancing resilience of critical ecosystem services for human well-being in the face of disturbance and ongoing change in complex social-ecological systems. These principles are (P1) maintain diversity and redundancy, (P2) manage connectivity, (P3) manage slow variables and feedbacks, (P4) foster an understanding of social-ecological systems as complex adaptive systems, (P5) encourage learning and experimentation, (P6) broaden participation, and (P7) promote polycentric governance systems. Quinlan et al. (2015) divided the principles along two axes by whether they focus primarily on the resilience of a social-ecological system or its governance, and by whether they focus on resilience based on system structure or its dynamics, strategies that are complementary and can be combined (Fig. 2).

Fig. 2. Principles for enhancing resilience in relation to the structure and dynamics of social-ecological systems and their analysis and management and governance (modified from Quinlan et al. 2015).

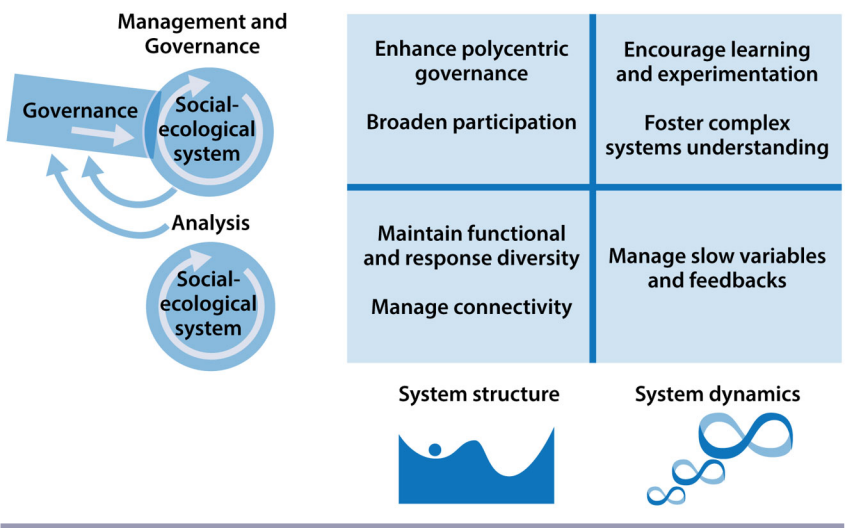

Briefly summarized, the principles stress that (P1) high levels of diversity and redundancy, but not too high, tend to make socialecological systems more resilient to change and provide options and flexibility for development; that (P2) connectivity needs to be managed for sources of resilience, for trust in networks, for new information, etc., but that there is a tension between too much connectivity versus modularity in complex social-ecological systems operating across levels and scales; that (P3) where known, changes in slow variables and feedbacks should be monitored with governance systems that can respond in a timely manner, and those supporting biosphere stewardship for ecosystem services and human well-being should be strengthened; that (P4) fostering complex adaptive-system thinking entails uncertainty, that tolerant cultures investigating potential nonlinearities and thresholds, allowing for diverse types of knowledge, and matching institutions and governance to complex adaptive system processes; that (P5) encouraging learning through experimentation and monitoring is essential for enabling adaptive responses and it requires social capital; that (P6) participation, and how it takes place, is facilitated, and the skills involved, is key for learning, building social capital and collective action; and finally, that (P7) polycentricity of governance enables the other resilience enhancing principles. Their implementation involves clarification of goals and developing and monitoring relevant metrics for each principle, taking an integrative approach that builds on multiple knowledge systems, shifting away from exclusively managing for efficiency toward planning for uncertainty and surprise, creating spaces for spontaneous exploration, and building trust and social capital (Biggs et al. 2015).

Such principles, whether for resilience building, collective action dilemmas (e.g., Ostrom 1990), or adaptive governance (e.g., Folke et al. 2005), should not be approached as end goals but rather as processes or mechanisms for generating conditions that allow for resolving collective-action challenges associated with multiple trade-offs in complex social-ecological systems. Such principles challenge the presumption that scholars can make simple, predictive models of social-ecological systems and deduce universal solutions, panaceas, to implement a certain principle (e.g., Holling et al. 1998, Ostrom 2007, Pahl-Wostl et al. 2012, Biggs et al. 2015, Clarvis et al. 2015). Rather, they support reflection, learning, and adaptation in search of deep understanding of complex, multivariable, nonlinear, cross-scale, and changing socialecological systems and how to relate this understanding for biosphere stewardship.

\section{CONCLUDING REMARKS}

Resilience thinking is an integrative approach for dealing with the sustainability challenge. It is about cultivating the capacity to sustain development in the face of change, incremental and abrupt, expected and surprising, in relation to diverse pathways and thresholds and tipping points between them. Resilience thinking can be viewed as a subset of sustainability science and has a strong focus on complex adaptive and truly intertwined social-ecological systems of people, communities, economies, societies, cultures interacting across spatial and temporal scales with ecosystems as part of the biosphere. The scale, speed, and connectivity of human actions in a globalized and intertwined world create new complex dynamics that play out in new, uncertain, and surprising ways and differently for different people and places. Resilience of a socialecological system refers to the capacity to develop and sustain human well-being in diverse contexts in the face of such change, both incremental and abrupt, but also through adapting or transforming in response to change.

Social-ecological systems are embedded in the biosphere. The biosphere connection is a central observation of resilience thinking, an observation that has to be explicit in work on resilience and social-ecological systems if sustainability is to be taken seriously. Confronted with planetary boundaries, it will become central for human well-being in the urbanized 21 st century to create incentives for transformation of human actions toward stewardship of complex adaptive social-ecological systems in ways that are in tune with the resilience of the biosphere. Well-being and development ultimately rests on biosphere capacity.

Responses to this article can be read online at: http://www.ecologyandsociety.org/issues/responses. php/9088

\section{Acknowledgments:}

Thanks in particular to Frances Westley, Elin Enfors, Magnus Nyström, Maja Schlüter, Oonsie Biggs, Lance Gunderson, and several 
other colleagues for providing constructive and inspiring comments on the manuscript that resulted in the Oxford Research Encyclopedia publication of which this article is a reprint. This review serves as a contribution to the GRAID-programme funded by Sida. It has also partly been supported by grants from the ErlingPersson Family Foundation and the Marianne and Marcus Wallenberg Foundation.

\section{LITERATURE CITED}

Abel, T., and J. R. Stepp. 2003. A new ecosystems ecology for anthropology. Conservation Ecology 7(3):12. http://dx.doi. org/10.5751/es-00579-070312

Adger, W. N. 2000. Social and ecological resilience: Are they related? Progress in Human Geography 24:347-364. http://dx.doi. org/10.1191/030913200701540465

Adger, W. N., J. Barnett, K. Brown, N. Marshall, and K. O’Brien. 2013. Cultural dimensions of climate change impacts and adaptation. Nature Climate Change 3:112-117. http://dx.doi. org/10.1038/nclimate1666

Adger, W. N., K. Brown, D. R. Nelson, F. Berkes, H. Eakin, C. Folke, K. Galvin, L. Gunderson, M. Goulden, K. O'Brien, j. Ruitenbeek, and E. L. Tompkins. 2011. Resilience implications of policy responses to climate change. WIREs Climate Change 2:757-766. http://dx.doi.org/10.1002/wcc.133

Adger, W. N., K, Brown, and E. L. Tompkins. 2005a. The political economy of cross-scale networks in resource co-management. Ecology and Society 10(2):9. [online] URL: http://www. ecologyandsociety.org/vol10/iss2/art9/

Adger, W. N., H. Eakin, and A. Winkels. 2009. Nested and teleconnected vulnerabilities to environmental change. Frontiers in Ecology and the Environment 7:150-157. http://dx.doi. org/10.1890/070148

Adger, W. N., T. P. Hughes, C. Folke, S. R. Carpenter, and J. Rockström. 2005b. Social-ecological resilience to coastal disasters. Science 309:1036-1039. http://dx.doi.org/10.1126/ science. 1112122

Allen, C. R., K. L. Pope, and J. J. Fontaine, editors. 2011. Adaptive management for natural resources. Journal of Environmental Management 92(5):1339-1428.

Allison, H. E., and R. J. Hobbs. 2004. Resilience, adaptive capacity, and the "lock-in trap" of the Western Australian agricultural region. Ecology and Society 9(1):3. http://dx.doi. org/10.5751/es-00641-090103

Amundsen, H. 2012. Illusions of resilience? An analysis of community responses to change in northern Norway. Ecology and Society 17(4):46. http://dx.doi.org/10.5751/es-05142-170446

Anderies, J. M. 2015. Managing variance: key policy challenges for the Anthropocene. Proceedings of the National Academy of Sciences of the USA 112:14402-14403. http://dx.doi.org/10.1073/ pnas. 1519071112

Anderies, J. M., C. Folke, B. Walker, and E. Ostrom. 2013. Aligning key concepts for global change policy: robustness, resilience, and sustainability. Ecology and Society 18(2):8. http:// dx.doi.org/10.5751/es-05178-180208
Andersson, E. 2006. Urban landscapes and sustainable cities. Ecology and Society 11(1):34. http://dx.doi.org/10.5751/ es-01639-110134

Andersson, E., S. Barthel, and K. Ahrné. 2007. Measuring socialecological dynamics behind the generation of ecosystem services. Ecological Applications 17:1267-1278. http://dx.doi.org/10.1890/06-1116.1

Andersson, E., S. Barthel, S. Borgström, J. Colding, T. Elmqvist, C. Folke, and Å. Gren. 2014. Reconnecting cities to the biosphere: stewardship of green infrastructure and urban ecosystem services. Ambio 43:445-453. http://dx.doi.org/10.1007/s13280-014-0506-y

Andrew, N. L., C. Béné, S. J. Hall, E. H. Allison, S. Heck, and B. D. Ratner. 2007. Diagnosis and management of small-scale fisheries in developing countries. Fish and Fisheries 8:227-240. http://dx.doi.org/10.1111/j.1467-2679.2007.00252.x

Armitage, D., F. Berkes, and N. Doubleday, editors. 2007. Adaptive co-management: collaboration, learning and multi-level governance. University of British Columbia Press, Vancouver, British Columbia, Canada.

Armitage, D. R., R. Plummer, F. Berkes, R. I. Arthur, A. T. Charles, I. J. Davidson-Hunt, A. P. Diduck, N. C. Doubleday, D. S. Johnson, M. Marschke, P. McConney, E. W. Pinkerton, and E. K. Wollenberg. 2009. Adaptive co-management for socialecological complexity. Frontiers in Ecology and the Environment 7:95-102. http://dx.doi.org/10.1890/070089

Arora-Jonsson, S. 2016. Does resilience have a culture? Ecocultures and the politics of knowledge production. Ecological Economics 121:98-107. http://dx.doi.org/10.1016/j.ecolecon.2015.11.020

Arrow, K., B. Bolin, R. Costanza, P. Dasgupta, C. Folke, C. S. Holling, B.-O. Jansson, S. Levin, K.-G. Mäler, C. Perrings, and D. Pimentel. 1995. Economic growth, carrying capacity, and the environment. Science 268:520-521. http://dx.doi.org/10.1126/ science. 268.5210 .520

Baggio, J. A., K. Brown, and D. Hellebrandt. 2015. Boundary object or bridging concept? A citation network analysis of resilience. Ecology and Society 20(2):2. http://dx.doi.org/10.5751/ es-07484-200202

Baird, J., R. Plummer, and K. Pickering. 2014. Priming the governance system for climate change adaptation: the application of a social-ecological inventory to engage actors in Niagara, Canada. Ecology and Society 19(1):3. http://dx.doi.org/10.5751/ es-06152-190103

Barnosky, A. D., E. A. Hadly, J. Bascompte, E. L. Berlow, J. H. Brown, M. Fortelius, W. M. Getz, J. Harte, A. Hastings, P. A. Marquet, N. D. Martinez, A. Mooers, P. Roopnarine, G. Vermeij, J. W. Williams, R. Gillespie, J. Kitzes, C. Marshall, N. Matzke, D. P. Mindell, E. Revilla, and A. B. Smith. 2012. Approaching a state shift in Earth's biosphere. Nature 486:52-58. http://dx.doi. org/10.1038/nature11018

Barrett, C. B., and M. A. Constas. 2014. Toward a theory of resilience for international development applications. Proceedings of the National Academy of Sciences of the USA 111:14625-14630. http://dx.doi.org/10.1073/pnas.1320880111

Barthel, S., C. Crumley, and U. Svedin. 2013. Bio-cultural refugia: safeguarding diversity of practices for food security and 
biodiversity. Global Environmental Change 23:1142-1152. http:// dx.doi.org/10.1016/j.gloenvcha.2013.05.001

Barthel, S., C. Folke, and J. Colding. 2010. Social-ecological memory in urban gardens: retaining the capacity for management of ecosystem services. Global Environmental Change 20:255-265. http://dx.doi.org/10.1016/j.gloenvcha.2010.01.001

Barthel, S., and C. Isendahl. 2013. Urban gardens, agriculture, and water management: sources of resilience for long-term food security in cities. Ecological Economics 86:224-234. http://dx.doi. org/10.1016/j.ecolecon.2012.06.018

Bellwood, D. R., T. P. Hughes, C. Folke, and M. Nyström. 2004. Confronting the coral reef crisis. Nature 429:827-833. http://dx. doi.org/10.1038/nature02691

Béné, C., D. Headey, L. Haddad, and K. von Grebmer. 2016. Is resilience a useful concept in the context of food security and nutrition programmes? Some conceptual and practical considerations. Food Security 8:123-138. http://dx.doi.org/10.1007/ s12571-015-0526-X

Bengtsson, J., P. Angelstam, T. Elmqvist, U. Emanuelsson, C. Folke, M. Ihse, F. Moberg, and M. Nyström. 2003. Reserves, resilience, and dynamic landscapes. Ambio 32:389-396. http://dx. doi.org/10.1579/0044-7447-32.6.389

Bennett, E. M., S. R. Carpenter, L. J. Gordon, N. Ramankutty, P. Balvanera, B. Campbell, W. Cramer, J. Foley, C. Folke, L. Karlberg, J. Liu, H. Lotze-Campen, N. D. Mueller, G. D. Peterson, S. Polasky, J. Rockström, R. J. Scholes, and M. Spierenburg. 2014. Toward a more resilient agriculture. Solutions 5(5):65-75.

Bennett, E. M., G. D. Peterson, and L. J. Gordon. 2009. Understanding relationships among multiple ecosystem services. Ecology Letters 12:1394-1404. http://dx.doi.org/10.1111/ j.1461-0248.2009.01387. $\mathrm{x}$

Berkes, F. 2007. Understanding uncertainty and reducing vulnerability: lessons from resilience thinking. Natural Hazards 41:283-295. http://dx.doi.org/10.1007/s11069-006-9036-7

Berkes, F. 2009. Evolution of co-management: role of knowledge generation, bridging organizations and social learning. Journal of Environmental Management 90:1692-1702. http://dx.doi.org/10.1016/ j.jenvman.2008.12.001

Berkes, F., J. Colding, and C. Folke, editors. 2003. Navigating social-ecological systems: building resilience for complexity and change. Cambridge University Press, Cambridge, UK. http://dx. doi.org/10.1017/cbo9780511541957

Berkes, F., and C. Folke, editors. 1998. Linking social and ecological systems: management practices and social mechanisms for building resilience. Cambridge University Press, Cambridge, UK.

Berkes, F., C. Folke, and J. Colding. 2000. Rediscovery of traditional ecological knowledge as adaptive management. Ecological Applications 10:1251-1262. http://dx.doi.org/10.1890/1051-0761 (2000)010[1251:ROTEKA]2.0.CO;2

Berkes, F., T. P. Hughes, R. S. Steneck, J. A. Wilson, D. R. Bellwood, B. Crona, C. Folke, L. H. Gunderson, H. M. Leslie, J.
Norberg, M. Nyström, P. Olsson, H. Österblom, M. Scheffer, and B. Worm. 2006. Globalization, roving bandits, and marine resources. Science 311:1557-1558. http://dx.doi.org/10.1126/ science. 1122804

Berkes, F., and D. Jolly. 2001. Adapting to climate change: socialecological resilience in a Canadian western Arctic community. Conservation Ecology 5(2):18. http://dx.doi.org/10.5751/es-00342-050218

Berkes, F., and H. Ross. 2013. Community resilience: toward an integrated approach. Society \& Natural Resources 26:5-20. http:// dx.doi.org/10.1080/08941920.2012.736605

Biermann, F., K. Abbott, S. Andresen, K. Bäckstrand, S. Bernstein, M. M. Betsill, H. Bulkeley, B. Cashore, J. Clapp, C. Folke, A. Gupta, J. Gupta, P. M. Haas, A. Jordan, N. Kanie, T. Kluvánková-Oravská, L. Lebel, D. Liverman, J. Meadowcroft, R. B. Mitchell, P. Newell, S. Oberthür, L. Olsson, P. Pattberg, R. Sánchez-Rodríguez, H. Schroeder, A. Underdal, S. Camargo Vieira, C. Vogel, O. R. Young., A. Brock, and R. Zondervan. 2012. Navigating the Anthropocene: improving Earth System Governance. Science 335:1306-1307. http://dx.doi.org/10.1126/ science. 1217255

Biggs, D., R. Biggs, V. Dakos, R. J. Scholes, and M. Schoon. 2011. Are we entering an era of concatenated global crises? Ecology and Society 16(2):27. [online] URL: http://www.ecologyandsociety. org/vol16/iss $2 / \operatorname{art} 27 /$

Biggs, R., T. Blenckner, C. Folke, L. Gordon, A. Norström, M. Nyström, and G. Peterson. 2012b. Regime shifts. Pages 609-617 in A. Hastings and L. Gross, editors. Encyclopedia in theoretical ecology. University of California Press, Berkeley, California, USA.

Biggs, R., S. R. Carpenter, and W. A. Brock. 2009. Turning back from the brink: detecting and impending regime shift in time to avert it. Proceedings of the National Academy of Sciences of the USA 106:826-831. http://dx.doi.org/10.1073/pnas.0811729106

Biggs, R., M. Schlüter, D. Biggs, E. L. Bohensky, S. BurnSilver, G. Cundill, V. Dakos, T. M. Daw, L. S. Evans, K. Kotschy, A. M. Leitch, C. Meek, A. Quinlan, C. Raudsepp-Hearne, M. D. Robarbs, M. L. Schoon, L. Schultz, and P. C.West. 2012a. Toward principles for enhancing the resilience of ecosystem services. Annual Review of Environment and Resources 37:421-448. http:// dx.doi.org/10.1146/annurev-environ-051211-123836

Biggs, R., M. Schlüter, and M. L. Schoon, editors. 2015. Principles for building resilience: sustaining ecosystem services in socialecological systems. Cambridge University Press, Cambridge, UK. http://dx.doi.org/10.1017/cbo9781316014240

Bodin, Ö., and B. I. Crona. 2009. The role of social networks in natural resource governance: what relational patterns make a difference? Global Environmental Change 19:366-374. http://dx. doi.org/10.1016/j.gloenvcha.2009.05.002

Bodin, Ö., and M. Tengö. 2012. Disentangling intangible socialecological systems. Global Environmental Change 22:430-439. http://dx.doi.org/10.1016/j.gloenvcha.2012.01.005

Bohensky, E. L., and Y. Maru. 2011. Indigenous knowledge, science, and resilience: what have we learned from a decade of international literature on "integration"? Ecology and Society 16 (4):6. http://dx.doi.org/10.5751/es-04342-160406 
Boonstra, W. 2016. Conceptualizing power to study socialecological interactions. Ecology and Society 21(1):21. http://dx. doi.org/10.5751/es-07966-210121

Bots, P. W. G., M. Schlüter, and J. Sendzimir. 2015. A framework for analyzing, comparing, and diagnosing social-ecological systems. Ecology and Society 20(4):18. http://dx.doi.org/10.5751/ es-08051-200418

Boulding, K. E. 1966. The economics of the coming spaceship Earth. Pages 3-14 in H. Jarrett, editor. Environmental quality in a growing economy. Resources for the Future/Johns Hopkins University Press, Baltimore, Maryland, USA.

Bourbeau, P. 2015. Resilience and international politics: premises, debates, agenda. International Studies Review 17:374-395. http:// dx.doi.org/10.1111/misr.12226

Bousquet, F., P. Robbins, C. Peloquin, and O. Bonato. 2015. The PISA grammar decodes diverse human-environment approaches. Global Environmental Change 34:159-171. http://dx.doi. org/10.1016/j.gloenvcha.2015.06.013

Boyd, E., R. J. Cornforth, P. J. Lamb, A. Tarhule, M. I. Lélé, and A. Brouder. 2013. Building resilience to face recurring environmental crisis in African Sahel. Nature Climate Change 3:631-637. http://dx.doi.org/10.1038/nclimate1969

Boyd, E., and C. Folke, editors. 2012. Adapting institutions: governance, complexity and social-ecological resilience. Cambridge University Press, Cambridge, UK. http://dx.doi.org/10.1017/ cbo9781139017237

Boyd, E., B. Nykvist, S. Borgström, and I. A. Stacewicz. 2015. Anticipatory governance for social-ecological resilience. Ambio 44:S149-161. http://dx.doi.org/10.1007/s13280-014-0604-X

Boyd, E., H. Osbahr, P. Ericksen, E. Tompkins, M. Lemos, and F. Miller. 2008. Resilience and 'climatizing' development: examples and policy implications. Development 51:390-396. http://dx.doi.org/10.1057/dev.2008.32

Brand, F. S., and K. Jax. 2007. Focusing the meaning(s) of resilience: resilience as a descriptive concept and a boundary object. Ecology and Society 12(1):23. http://dx.doi.org/10.5751/ $\underline{\text { es-02029-120123 }}$

Brondizio, E. S., K. O’Brien, X. Bai, F. Biermann, W. Steffen, F. Berkhout, C. Cudennec, M. C. Lemos, A. Wolfe, J. PalmaOliveira, C.-T. A. Chen. 2016. Re-conceptualizing the Anthropocene: a call for collaboration. Global Environmental Change 39:318-327. http://dx.doi.org/10.1016/j.gloenvcha.2016.02.006

Brown, K. 2014. Global environmental change I: a social turn for resilience? Progress in Human Geography 38:107-117. http://dx. doi.org/10.1177/0309132513498837

Brown, K. 2016. Resilience, development and global change. Routledge, London, UK.

Brown, K., and E. Westaway. 2011. Agency, capacity, and resilience to environmental change: lessons from human development, well-being, and disasters. Annual Review of Environment and Resources 36:321-342. http://dx.doi.org/10.1146/ annurev-environ-052610-092905
Capistrano, D., C. Samper, M. J. Lee, and C. Raudsepp-Hearne, editors. 2006. Ecosystems and human well-being: multiscale assessments: findings of the Sub-global Assessments Working Group. Millennium Ecosystem Assessment Series. Island, Washington, D.C., USA.

Carpenter, S. R. 2003. Regime shifts in lake ecosystems: pattern and variation. Excellence in Ecology 15. International Ecology Institute, Oldendorf, Germany.

Carpenter, S. R., K. J. Arrow, S. Barrett, R. Biggs, W. A. Brock, A.-S. Crépin, G. Engström, C. Folke, T. Hughes, N. Kautsky, C.Z. Li, G. McCarney, K. Meng, K.-G. Mäler, S. Polasky, M. Scheffer, J. Shogren, T. Sterner, J. Vincent, B. Walker, A. Xepapadeas, and A. de Zeeuw. 2012a. General resilience to cope with extreme events. Sustainability 4:3248-3259. http://dx.doi. org/10.3390/su4123248

Carpenter, S. R., E. M. Bennett, and G. D. Peterson. 2006. Scenarios for ecosystem services: an overview. Ecology and Society 11(1):29. http://dx.doi.org/10.5751/es-01610-110129

Carpenter, S. R., E. G. Booth, S. Gillon, C. J. Kucharik, S. Loheide, A. S. Mase, M. Motew, J. Qiu, A. R. Rissman, J. Seifert, E. Soylu, M. Turner, and C. B. Wardropper. 2015b. Plausible futures of a social-ecological system: Yahara watershed, Wisconsin, USA. Ecology and Society 20(2):10. http://dx.doi. org/10.5751/ES-07433-200210

Carpenter, S. R., and W. A. Brock. 2008. Adaptive capacity and traps. Ecology and Society 13(2):40. http://dx.doi.org/10.5751/ es-02716-130240

Carpenter, S. R., W. A. Brock, C. Folke, E. van Nes, and M. Scheffer. 2015a. Allowing variance may enlarge the safe operating space for exploited ecosystems. Proceedings of the National Academy of Sciences of the USA 112:14384-14389. http://dx.doi. org/10.1073/pnas.1511804112

Carpenter, S. R., C. Folke, A. Norström, O. Olsson, L. Schultz, B. Agarwal, P. Balvanera, B. Campbell, J. C. Castilla, W. Cramer, R. DeFries, P. Eyzaguirre, T. Hughes, S. Polasky, Z. Sanusi, R. Scholes, and M. Spierenburg. 2012b. Program on ecosystem change and society: an international research strategy for integrated social-ecological systems. Current Opinion in Environmental Sustainability 4:134-138. http://dx.doi.org/10.1016/ j.cosust.2012.01.001

Carpenter, S. R., C. Folke, M. Scheffer, and F. Westley. $2009 b$. Resilience: accounting for the noncomputable. Ecology and Society 14(1):13. [online] URL: http://www.ecologyandsociety. org/vol14/iss1/art13/

Carpenter, S. R., H. A. Mooney, J. Agard, D. Capistrano, R. S. DeFries, S. Diaz, T. Dietz, A. K. Duraiappah, A. Oteng-Yeboah, H. M. Pereira, C. Perrings, W. V. Reid, J. Sarukhan, R. J. Scholes, and A. Whyte. 2009a. Science for managing ecosystem services: beyond the Millennium Ecosystem Assessment. Proceedings of the National Academy of Sciences, USA 106:1305-1312. http://dx. doi.org/10.1073/pnas.0808772106

Carpenter, S. R., B. H. Walker, J. M. Anderies, and N. Abel. 2001. From metaphor to measurement: resilience of what to what? Ecosystems 4:765-781. http://dx.doi.org/10.1007/s10021-001-0045-9 
Carpenter, S. R., F. Westley, and M. G. Turner. 2005. Surrogates for resilience of social-ecological systems. Ecosystems 8:941-944. http://dx.doi.org/10.1007/s10021-005-0170-y

Cash, D. W., W. Adger, F. Berkes, P. Garden, L. Lebel, P. Olsson, L. Pritchard, and O. Young. 2006. Scale and cross-scale dynamics: governance and information in a multilevel world. Ecology and Society 11(2):8. http://dx.doi.org/10.5751/es-01759-110208

Chaffin, B. C., H. Gosnell, and B. A. Cosens. 2014. A decade of adaptive governance scholarship: synthesis and future directions. Ecology and Society 19(3):56. http://dx.doi.org/10.5751/ es-06824-190356

Chandler, D. 2014. Beyond neoliberalism: resilience, the new art of governing complexity. Resilience 2:47-63. http://dx.doi. org/10.1080/21693293.2013.878544

Chapin, F. S. III, S. R. Carpenter, G. P. Kofinas, C. Folke, N. Abel, W. C. Clark, P. Olsson, D. M. Stafford Smith, B. H. Walker, O. R. Young, F. Berkes, R. Biggs, J. M. Grove, R. L. Naylor, E. Pinkerton, W. Steffen, and F. J. Swanson. 2010. Ecosystem stewardship: sustainability strategies for a rapidly changing planet. Trends in Ecology and Evolution 25:241-249. http://dx.doi. org/10.1016/j.tree.2009.10.008

Chapin, F. S. III, G. P. Kofinas, and C. Folke, editors. 2009. Principles of ecosystem stewardship: resilience-based natural resource management in a changing world. Springer Verlag, New York, New York, USA.

Chapin, F. S. III, A. L. Lovecraft, E. S. Zavaleta, J. Nelson, M. D. Robards, G. P. Kofinas, S. F. Trainor, G. D. Peterson, H. P. Huntington, and R. L. Naylor. 2006. Policy strategies to address sustainability of Alaskan boreal forests in response to a directionally changing climate. Proceedings of the National Academy of Sciences of the USA 103:16637-16643. http://dx.doi. org/10.1073/pnas.0606955103

Cifdaloz, O., A. Regmi, J. M. Anderies, and A. A. Rodriguez. 2010. Robustness, vulnerability, and adaptive capacity in smallscale social-ecological systems: the Pumpa Irrigation system in Nepal. Ecology and Society 15(3):39. [online] URL: http://www. ecologyandsociety.org/vol15/iss3/art39/

Cillier, P. 2008. Complexity theory as a general framework for sustainability science. Pages 39-57 in M. Burns and A. Weaver, editors. Exploring sustainability science: a Southern African perspective. Sun Press, Stellenbosch, South Africa.

Cinner, J. E., C. Hutchery, C. C. Hicks, T. M. Daw, N. Marshall, A. Wamukota, and E. H. Allison. 2015. Changes in adaptive capacity of Kenyan fishing communities. Nature Climate Change 5:872-876. http://dx.doi.org/10.1038/nclimate2690

Cinner, J. E., T. R. McClanahan, M. A. MacNeil, N. A. J. Graham, T. M. Daw, A. Mukminin, D. A. Feary, A. L. Rabearisoa, A. Wamukota, N. Jiddawi, S. J. Campbell, A. H. Baird, F. A. Januchowski-Hartley, S. Hamed, R. Lahari, T. Morove, and J. Kuange. 2012. Comanagement of coral reef social-ecological systems. Proceedings of the National Academy of Sciences of the USA 109:5219-5222. http://dx.doi.org/10.1073/pnas.1121215109

Clark, W. C. 2007. Sustainability science: a room of its own. Proceedings of the National Academy of Sciences of the USA 104:1737-1738. http://dx.doi.org/10.1073/pnas.0611291104
Clark, W. C., D. D. Jones, and C. S. Holling. 1979. Lessons for ecological policy design: a case study of ecosystem management. Ecological Modelling 7:1-53. http://dx.doi.org/10.1016/0304-3800 (79)90008-5

Clark, W. C., and R. E. Munn, editors. 1986. Sustainable development of the biosphere. Cambridge University Press, Cambridge, UK. https://doi.org/10.1017/S0266467400004168

Clarvis, M. H., E. Bohensky, and M. Yarime. 2015. Can resilience thinking inform resilience investments? Learning from resilience principles for disaster risk reduction. Sustainability 7:9048-9066. http://dx.doi.org/10.3390/su7079048

Colding, J. 2007. 'Ecological land-use complementation' for building resilience in urban ecosystems. Landscape and Urban Planning 81:46-55. http://dx.doi.org/10.1016/j.landurbplan.2006.10.016

Colding, J., and S. Barthel. 2013. The potential of 'Urban Green Commons' in the resilience building of cities. Ecological Economics 86:156-166. http://dx.doi.org/10.1016/j.ecolecon.2012.10.016

Colding, J., J. Lundberg, and C. Folke. 2006. Incorporating greenarea user groups in urban ecosystem management. Ambio 35:237-244. http://dx.doi.org/10.1579/05-A-098R.1

Connolly, J. J. T, E. S. Svendsen, D. R. Fisher, and L. K. Campbell. 2014. Networked governance and the management of ecosystem services: the case of urban environmental stewardship in New York City. Ecosystem Services 10:187-194. http://dx.doi. org/10.1016/j.ecoser.2014.08.005

Cosens, B. A. 2013. Legitimacy, adaptation, and resilience in ecosystem management. Ecology and Society 18(1):3. http://dx. doi.org/10.5751/ES-05093-180103

Cosens, B. A., and M. K. Williams. 2012. Resilience and water governance: adaptive governance in the Columbia River basin. Ecology and Society 17(4):3. http://dx.doi.org/10.5751/ES-04986-170403

Costanza, R. 2001. Visions, values, valuation, and the need for an ecological economics. BioScience 51:459-468. http://dx.doi. org/10.1641/0006-3568(2001)051[0459:VVVATN]2.0.CO;2

Costanza, R., H. Daly, C. Folke, P. Hawken, C. S. Holling, T. McMichael, D. Pimentel, and D. Rapport. 2000. Managing our environmental portfolio. BioScience 50:149-155. http://dx.doi. org/10.1641/0006-3568(2000)050[0149:MOEP]2.3.CO;2

Costanza, R., L. Waigner, C. Folke, and K.-G. Mäler. 1993. Modeling complex ecological economic systems: toward an evolutionary, dynamic understanding of people and nature. BioScience 43:545-555. http://dx.doi.org/10.2307/1311949

Crane, T. A. 2010. Of models and meanings: cultural resilience in social-ecological systems. Ecology and Society 15(4):19. [online] URL: http://www.ecologyandsociety.org/vol15/iss4/art19/

Crépin, A.-S., R. Biggs, S. Polasky, M. Troell, and A. de Zeeuw. 2012. Regime shifts and management. Ecological Economics 84:15-22. http://dx.doi.org/10.1016/j.ecolecon.2012.09.003

Cretney, R. 2014. Resilience for whom? Emerging critical geographies of socio-ecological resilience. Geography Compass 8:627-640. http://dx.doi.org/10.1111/gec3.12154

Crona, B., and Ö. Bodin. 2006. What you know is who you know? Communication patterns among resource users as a prerequisite 
for co-management. Ecology and Society 11(2):7. http://dx.doi. org/10.5751/es-01793-110207

Crona, B., and Ö. Bodin. 2010. Power asymmetries in small-scale fisheries: a barrier to governance transformability? Ecology and Society 15(4):32. [online] URL: http://www.ecologyandsociety. org/vol15/iss4/art32/

Crona, B. I., and J. N. Parker. 2012. Learning in support of governance: theories, methods, and a framework to assess how bridging organizations contribute to adaptive resource governance. Ecology and Society 17(1):32. http://dx.doi. org/10.5751/es-04534-170132

Crona, B. I., T. Van Holt, M. Petersson, T. M. Daw, and E. Buchary. 2015. Using social-ecological syndromes to understand impacts of international seafood trade on small-scale fisheries. Global Environmental Change 35:162-175. http://dx.doi. org/10.1016/j.gloenvcha.2015.07.006

Cumming, G. S. 2011. Spatial resilience of social-ecological systems. Springer Verlag, New York, New York, USA. http://dx. doi.org/10.1007/978-94-007-0307-0

Cumming, G. S., A. Buerkert, E. M. Hoffmann, E. Schlecht, S. von Cramon-Taubadel, and T. Tscharntke. 2014. Implications of agricultural transitions and urbanization for ecosystem services. Nature 515:50-57. http://dx.doi.org/10.1038/nature13945

Cumming, G. S., and J. Collier. 2005. Change and identity in complex systems. Ecology and Society 10(1):29. http://dx.doi. org/10.5751/es-01252-100129

Cumming, G. S., P. Olsson, F. S. Chapin III, and C. S. Holling. 2013. Resilience, experimentation, and scale mismatches in socialecological landscapes. Landscape Ecology 28:1139-1150. http:// dx.doi.org/10.1007/s10980-012-9725-4

Curtin, C. G., and J. P. Parker. 2014. Foundations of resilience thinking. Conservation Biology 28:912-923. http://dx.doi. org/10.1111/cobi.12321

Cury, P. M., I. L. Boyd, S. Bonhommeau, T. Anker-Nilssen, R. J. M. Crawford, R. W. Furness, J. A. Mills, E. J. Murphy, H. Österblom, M. Paleczny, J. F. Piatt, J.-P. Roux, L. Shannon, and W. J. Sydeman. 2011. Global seabird response to forage fish depletion: one-third for the birds. Science 334:1703-1706. http:// dx.doi.org/10.1126/science. 1212928

Daily, G. C., and P. R. Ehrlich. 1992. Population, sustainability, and Earth's carrying capacity. BioScience 42:761-771. http://dx. doi.org/10.2307/1311995

Dakos, V., M. Scheffer, E. H. van Nes, V. Brovkin, V. Petoukhov, and H. Held. 2008. Slowing down as an early warning signal for abrupt climate change. Proceedings of the National Academy of Sciences of the USA 105:14308-14312. http://dx.doi.org/10.1073/ pnas.0802430105

Dasgupta, P., and K.-G. Mäler, editors. 2004. The economics of non-convex ecosystems. Kluwer Academic, Dordrecht, The Netherlands. http://dx.doi.org/10.1007/1-4020-2515-7

Davidson-Hunt, I. J., and F. Berkes. 2003. Nature and society through the lens of resilience: toward a human-in-ecosystem perspective. Pages 53-82 in F. Berkes, J. Colding, and C. Folke, editors. Navigating social-ecological systems: building resilience for complexity and change. Cambridge University Press, Cambridge, UK. http://dx.doi.org/10.1017/cbo9780511541957.006

Davies, M., C. Béné, A. Arnall, T. Tanner, A. Newsham, and C. Coirolo. 2013. Promoting resilient livelihoods through adaptive social protection: lessons from 124 programmes in South Asia. Development Policy Review 31:27-58. http://dx.doi.org/10.1111/ j.1467-7679.2013.00600.x

Daw, T., S. Coulthard, W. W. L .Cheung, K. Brown, C. Abunge, D. Galafassi, G. D. Peterson, T. R. McClanahan, J. O. Omukoto, and L. Munyi. 2015. Evaluating taboo trade-offs in ecosystems services and human well-being. Proceedings of the National Academy of Sciences of the USA 112:6949-6954. http://dx.doi. org/10.1073/pnas.1414900112

Desjardins, E., G. Barker, Z. Lindo, C. Dieleman, and A. C. Dussault. 2015. Promoting resilience. Quarterly Review of Biology 90:147-165. http://dx.doi.org/10.1086/681439

Deutsch, L., S. Gräslund, C. Folke, M. Troell, M. Huitric, N. Kautsky, and L. Lebel. 2007. Feeding aquaculture growth through globalization: exploitation of marine ecosystems for fishmeal. Global Environmental Change 17:238-249. http://dx.doi. org/10.1016/j.gloenvcha.2006.08.004

de Zeeuw, A. 2014. Regime shifts in resource management. Annual Review of Resource Economics 6:85-104. http://dx.doi. org/10.1146/annurev-resource-100913-012405

Díaz, S., F. Quétier, D. M. Cáceres, S. F. Trainor, N. PérezHarguindeguy, M. S. Bret-Harte, B. Finegan, M. Peña-Claros, and L. Poorter. 2011. Linking functional diversity and social actor strategies in a framework for interdisciplinary analysis of nature's benefits to society. Proceedings of the National Academy of Sciences of the USA 108:895-902. http://dx.doi.org/10.1073/ pnas. 1017993108

Dietz, T., E. Ostrom, and P. C. Stern. 2003. The struggle to govern the commons. Science 302:1907-1912. http://dx.doi.org/10.1126/ $\underline{\text { science. } 1091015}$

Djalante, R., C. Holley, F. Thomalla, and M. Carnegie. 2013. Pathways for adaptive and integrated disaster resilience. Natural Hazards 69:2105-2135. http://dx.doi.org/10.1007/s11069-013-0797-5

Duit, A., V. Galaz, K. Eckerberg, and J. Ebbesson. 2010. Governance, complexity, and resilience. Global Environmental Change 20:363-368. http://dx.doi.org/10.1016/j.gloenvcha.2010.04.006

Ebbesson, J. 2010. The rule of law in governance of complex socioecological changes. Global Environmental Change 20:414-422. http://dx.doi.org/10.1016/j.gloenvcha.2009.10.009

Ebbesson, J., and E. Hey. 2013. Introduction: Where in law is social-ecological resilience? Ecology and Society 18(3):25. http:// dx.doi.org/10.5751/ES-05750-180325

Ekstrom, J. A., and O. R. Young. 2009. Evaluating functional fit between a set of institutions and an ecosystem. Ecology and Society 14(2):16. http://dx.doi.org/10.5751/es-02930-140216

Ellis, E. C. 2015. Ecology in an anthropogenic biosphere. Ecological Monographs 85:287-331. http://dx.doi.org/10.1890/14-2274.1 
Elmqvist, T., C. Folke, M. Nyström, G. Peterson, J. Bengtsson, B. Walker, and J. Norberg. 2003. Response diversity, ecosystem change, and resilience. Frontiers in Ecology and the Environment 1:488-494. http://dx.doi.org/10.1890/1540-9295(2003)001[0488: RDECAR]2.0.CO;2

Elmqvist, T., M. Fragkias, J. Goodness, B. Güneralp, P. J. Marcotullio, R. I. McDonald, S. Parnell, M. Schewenius, M. Sendstad, K. Seto, and C. Wilkinson, editors. 2013. Urbanization, biodiversity and ecosystem services: challenges and opportunities. Springer, New York, New York, USA. http://dx.doi. org/10.1007/978-94-007-7088-1

Enfors, E. 2013. Social-ecological traps and transformations in dryland agro-ecosystems: using water system innovations to change the trajectory of development. Global Environmental Change 23:51-60. http://dx.doi.org/10.1016/j.gloenvcha.2012.10.007

Enfors, E. I., L. J. Gordon, G. D. Peterson, and D. Bossio. 2008. Making investments in dryland development work: participatory scenario planning in the Makanya catchment, Tanzania. Ecology and Society 13(2):42. [online] URL: http://www.ecologyandsociety. org/vol13/iss2/art42/ http://dx.doi.org/10.5751/es-02649-130242

Engle, N. L. 2011. Adaptive capacity and its assessment. Global Environmental Change 21:647-656. http://dx.doi.org/10.1016/j. gloenvcha.2011.01.019

Eriksson, H., H. Österblom, B. Crona, M. Troell, N. Andrew, J. Wilen, and C. Folke. 2015. Contagious exploitation of marine resources. Frontiers in Ecology and the Environment 13:435-440. http://dx.doi.org/10.1890/140312

Ernstson, H., S. Barthel, E. Andersson, and S. T. Borgström. 2010. Scale-crossing brokers and network governance of urban ecosystem services: the case of Stockholm. Ecology and Society 15(4):28. [online] URL: http://www.ecologyandsociety.org/vol15/ iss4/art 281

Ernstson, H., S. Sörlin, and T. Elmqvist. 2008. Social movements and ecosystem services: the role of social network structure in protecting and managing urban green areas in Stockholm. Ecology and Society 13(2):39. [online] URL: http://www. ecologyandsociety.org/vol13/iss2/art39/

Fairhead, J., M. Leach, and I. Scoones. 2012. Green grabbing: a new appropriation of nature? Journal of Peasant Studies 39:237-261. http://dx.doi.org/10.1080/03066150.2012.671770

Fazey, I., J. A. Fazey, J. Fischer, K. Sherren, J. Warren, R. F. Noss, and S. R. Dovers. 2007. Adaptive capacity and learning to learn as leverage for social-ecological resilience. Frontiers in Ecology and the Environment 5:375-380. http://dx.doi.org/10.1890/1540-9295 (2007)5[375:ACALTL]2.0.CO;2

Feola, G. 2015. Societal transformation in response to global environmental change: a review of emerging concepts. Ambio 44:376-390. http://dx.doi.org/10.1007/s13280-014-0582-Z

Fernández-Giménez, M. E. 2015. "A shepherd has to invent": poetic analysis of social-ecological change in the cultural landscape of the central Spanish Pyrenees. Ecology and Society 20(4):29. http://dx.doi.org/10.5751/ES-08054-200429

Fischer, J., T. A. Gardner, E. B. Bennett, P. Balvanera, R. Biggs, S. R. Carpenter, T. Daw, C. Folke, R. Hill, T. Hughes, T. Luthe,
M. Maass, M. Meacham, A. V. Norström, G. Peterson, C. Queiroz, R. Seppelt, M. Spierenburg, and J. Tenhunen. 2015. Advancing sustainability through mainstreaming a socialecological systems perspective. Current Opinion in Environmental Sustainability 14:144-149. http://dx.doi.org/10.1016/j.cosust.2015.06.002

Fischer-Kowalski, M., and J. Rotmans. 2009. Conceptualizing, observing, and influencing social-ecological transitions. Ecology and Society 14(2):3. [online] URL: http://www.ecologyandsociety. org/vol14/iss2/art3/

Folke, C. 2006. Resilience: the emergence of a perspective for social-ecological systems analyses. Global Environmental Change 16:253-267. http://dx.doi.org/10.1016/j.gloenvcha.2006.04.002

Folke, C. 2016. Resilience. In H. Shugart, Editor-in-Chief. Subject: Framing concepts in environmental science. Oxford research encyclopedias, environmental science. Oxford University Press, New York, New York, USA. http://dx.doi.org/10.1093/ acrefore/9780199389414.013.8

Folke, C., S. Carpenter, T. Elmqvist, L. Gunderson, C. S. Holling, and B. Walker. 2002. Resilience and sustainable development: building adaptive capacity in a world of transformations. Ambio 31:437-440. http://dx.doi.org/10.1579/0044-7447-31.5.437

Folke, C., S. R. Carpenter, B. H. Walker, M. Scheffer, F. S. Chapin III, and J. Rockström. 2010. Resilience thinking: integrating resilience, adaptability and transformability. Ecology and Society 15(4):20. [online] URL: http://www.ecologyandsociety.org/vol15/ iss $4 /$ art $20 /$

Folke, C., S. R. Carpenter, B. H. Walker, M. Scheffer, T. Elmqvist, L. Gunderson, and C. S. Holling. 2004. Regime shifts, resilience and biodiversity in ecosystem management. Annual Review of Ecology, Evolution and Systematics 35:557-581. http://dx.doi. org/10.1146/annurev.ecolsys.35.021103.105711

Folke, C., F. S. Chapin III, and P. Olsson. 2009. Transformations in ecosystem stewardship. Pages 103-125 in C. Folke, G. P. Kofinas, and F. S. Chapin III, editors. Principles of ecosystem stewardship: resilience-based natural resource management in a changing world. Springer Verlag, New York, New York, USA. http://dx.doi. org/10.1007/978-0-387-73033-2 5

Folke, C., J. Colding, and F. Berkes. 2003. Synthesis: building resilience and adaptive capacity in social-ecological systems. Pages 352-387 in F. Berkes, J. Colding, and C. Folke, editors. Navigating social-ecological systems: building resilience for complexity and change. Cambridge University Press, Cambridge, UK. http://dx.doi.org/10.1017/cbo9780511541957.020

Folke, C., T. Hahn, P. Olsson, and J. Norberg. 2005. Adaptive governance of social-ecological systems. Annual Review of Environment and Resources 30:441-473. http://dx.doi.org/10.1146/ annurev.energy.30.050504.144511

Folke, C., C. S. Holling, and C. A. Perrings. 1996. Biological diversity, ecosystems and the human scale. Ecological Applications 6:1018-1024. http://dx.doi.org/10.2307/2269584

Folke, C., Å. Jansson, J. Larsson, and R. Costanza. 1997. Ecosystem appropriation by cities. Ambio 26:167-172.

Folke, C., Å. Jansson, J. Rockström, P. Olsson, S. R. Carpenter, F. S. Chapin III, A.-S. Crépin, G. Daily, K. Danell, J. Ebbesson, 
T. Elmqvist, V. Galaz, F. Moberg, M. Nilsson, H. Österblom, E. Ostrom, A. Persson, G. Peterson, S. Polasky, W. Steffen, B. Walker, and F. Westley. 2011. Reconnecting to the biosphere. Ambio 40:719-738. http://dx.doi.org/10.1007/s13280-011-0184-y

Forbes, B. C. 2013. Cultural resilience of social-ecological systems in the Nenets and Yamal-Nenets Autonomous Okrugs, Russia: a focus on reindeer nomads of the tundra. Ecology and Society 18 (4):36. http://dx.doi.org/10.5751/es-05791-180436

Forbes, B. C., F. Stammler, T. Kumpula, N. Meschtyb, A. Pajunen, and E. Kaarlejärvi. 2009. High resilience in the Yamal-Nenets social-ecological system, West Siberian Arctic, Russia. Proceedings of the National Academy of Sciences of the USA 106:22041-22048. http://dx.doi.org/10.1073/pnas.0908286106

Gadgil, M., F. Berkes, and C. Folke. 1993. Indigenous knowledge for biodiversity conservation. Ambio 22:151-156.

Galaz, V. 2005. Social-ecological resilience and social conflict: institutions and strategic adaptation in Swedish water management. Ambio 34:567-572. http://dx.doi.org/10.1579/0044$\underline{-7447-34.7 .567}$

Galaz, V. 2014. Global environmental governance, technology and politics: the Anthropocene gap. Edward Elgar, Cheltenham, UK. http://dx.doi.org/10.4337/9781781955550

Galaz, V., F. Biermann, B. Crona, D. Loorbach, C. Folke, P. Olsson, M. Nilsson, J. Allouche, A. Persson, and G. Rieschl. 2012a. Planetary boundaries: exploring the challenges for global environmental governance. Current Opinion in Environmental Sustainability 4:80-87. http://dx.doi.org/10.1016/j.cosust.2012.01.006

Galaz, V., B. Crona, H. Österblom, P. Olsson, and C. Folke. $2012 b$. Polycentric systems and interacting planetary boundaries: emerging governance of climate change - ocean acidification marine biodiversity. Ecological Economics 81:21-32. http://dx. doi.org/10.1016/j.ecolecon.2011.11.012

Galaz, V., J. Gars, F. Moberg, B. Nykvist, and C. Repinski. 2015. Why ecologists should care about financial markets. Trends in Ecology and Evolution 30:571-580. http://dx.doi.org/10.1016/j. tree.2015.06.015

Galaz, V., T. Hahn, P. Olsson, C. Folke, and U. Svedin. 2008. The problem of fit among biophysical systems, environmental regimes, and broader governance systems: insights and emerging challenges. Pages 147-186 in O. Young, L. A. King, and H. Schroeder, editors. Institutions and environmental change: principal findings, applications, and research frontiers. MIT Press, Cambridge, Massachusetts, USA. http://dx.doi.org/10.7551/ mitpress/9780262240574.003.0005

Galaz, V., F. Moberg, F. Olsson, E.-K. Olsson, E. Paglia, and C. Parker. 2011. Institutional and political leadership dimensions of cascading ecological crises. Public Administration 89:361-380. http://dx.doi.org/10.1111/j.1467-9299.2010.01883.x

Garmestani, A. S., C. R. Allen, and M. H. Benson. 2013. Can law foster social-ecological resilience? Ecology and Society 18(2):37. http://dx.doi.org/10.5751/ES-05927-180237

Geels, F. W., and R. Kemp. 2006. Transitions, transformations, and reproduction: dynamics in socio-technical systems. Pages 227-257 in M. D. McKelvey and M. Holmén, editors. Flexibility and stability in the innovating economy. Oxford Scholarship Online Monographs, Oxford, UK. http://dx.doi.org/10.1093/01992904$\underline{74.003 .0009}$

Geertz, C. 1973. The interpretation of cultures: selected essays. Basic Books, New York, New York, USA.

Gelcich, S., G. Edwards-Jones, M. J. Kaiser, and J. C. Castilla. 2006. Co-management policy can reduce resilience in traditionally managed marine ecosystems. Ecosystems 9:951-966. http://dx.doi.org/10.1007/s10021-005-0007-8

Gelcich, S., T. P. Hughes, P. Olsson, C. Folke, O. Defeo, M. Fernández, S. Foale, L. H. Gunderson, C. Rodríguez-Sickert, M. Scheffer, R. Steneck, and J. C. Castilla. 2010. Navigating transformations in governance of Chilean marine coastal resources. Proceedings of the National Academy of Sciences of the USA 107:16794-16799. http://dx.doi.org/10.1073/pnas.1012021107

Goldstein, B. E., editor. 2012. Collaborative resilience: moving through crisis to opportunity. MIT Press, Cambridge, Massachusetts, USA.

Gómez-Baggethun, E., and D. N. Barton. 2013. Classifying and valuing ecosystem services for urban planning. Ecological Economics 86:235-245. http://dx.doi.org/10.1016/j.ecolecon.2012.08.019

Gómez-Baggethun, E., E. Corbera, and V. Reyes-García. 2013. Traditional ecological knowledge and global environmental change: research findings and policy implications. Ecology and Society 18(4):72. http://dx.doi.org/10.5751/es-06288-180472

Gordon, L. J., G. D. Peterson, and E. M. Bennett. 2008. Agricultural modifications of hydrological flows create ecological surprises. Trends in Ecology and Evolution 23:211-219. http://dx. doi.org/10.1016/j.tree.2007.11.011

Goulden, M. C., W. N. Adger, E. H. Allison, and D. Conway. 2013. Limits to resilience from livelihood diversification and social capital in lake social-ecological systems. Annals of the Association of American Geographers 103:906-924. http://dx.doi. org/10.1080/00045608.2013.765771

Graham, N. A. J., D. R. Bellwood, J. E. Cinner, T. P. Hughes, A. V. Norström, and M. Nyström. 2013. Managing resilience to reverse phase shifts in coral reefs. Frontiers in Ecology and the Environment 11:541-548. http://dx.doi.org/10.1890/120305

Green, O. O., A. S. Garmestani, H. F. M. W. Van Rijswick, and A. M. Keessen. 2013. EU water governance: striking the right balance between regulatory flexibility and enforcement? Ecology and Society 18(2):10. http://dx.doi.org/10.5751/es-05357-180210

Grimm, N. B., S. H. Faeth, N. E. Golubiewski, C. L. Redman, J. G. Wu, X. M. Bai, and J. M. Briggs. 2008. Global change and the ecology of cities. Science 319:756-760. http://dx.doi.org/10.1126/ science. 1150195

Guerry, A. D., S. Polasky, J. Lubchenco, R. Chaplin-Kramer, G. C. Daily, R. Griffin, M. H. Ruckelshaus, I. Bateman, A. Duraiappah, T. Elmqvist, M. W. Feldman, C. Folke, J. Hoekstra, P. Kareiva, B. Keeler, S. Li, E. McKenzie, Z. Ouyang, B. Reyers, T. Ricketts, J. Rockström, H. Tallis, and B. Vira. 2015. Natural capital informing decisions: from promise to practice. Proceedings of the National Academy of Sciences of the USA 112:7348-7355. http://dx.doi.org/10.1073/pnas.1503751112 
Gunderson, L. H. 2000. Ecological resilience-in theory and application. Annual Review of Ecology and Systematics 31:425-439. http://dx.doi.org/10.1146/annurev.ecolsys.31.1.425

Gunderson, L. H. 2001. Managing surprising ecosystems in southern Florida. Ecological Economics 37:371-378. http://dx. doi.org/10.1016/S0921-8009(01)00179-3

Gunderson, L. H., C. R. Allen, and C. S. Holling, editors. 2009. Foundations of ecological resilience. Island, Washington, D.C., USA.

Gunderson, L. H., and C. S. Holling, editors. 2002. Panarchy: understanding transformations in human and natural systems. Island, Washington, D.C., USA.

Gunderson, L. H., C. S. Holling, and S. S. Light, editors. 1995. Barriers and bridges to the renewal of ecosystems and institutions. Columbia University Press, New York, New York, USA.

Gunderson, L. H., and L. Pritchard, editors. 2002. Resilience and the behavior of large-scale systems. Island, Washington, D.C., USA.

Hahn, T. 2011. Self-organized governance networks for ecosystem management: Who is accountable? Ecology and Society 16(2):18. http://dx.doi.org/10.5751/ES-04043-160218

Hahn, T., P. Olsson, C. Folke, and K. Johansson. 2006. Trust building, knowledge generation and organizational innovations: the role of a bridging organization for adaptive comanagement of a wetland landscape around Kristianstad, Sweden. Human Ecology 34:573-592. http://dx.doi.org/10.1007/s10745-006-9035$\underline{\mathrm{Z}}$

Haider, J., A. E. Quinlan, and G. D. Peterson. 2012. Interacting traps: resilience assessment of a pasture system in northern Afghanistan. Planning Theory and Practice 13:312-319.

Hall, P. A., and M. Lamont, editors. 2013. Social resilience in the neoliberal era. Cambridge University Press, New York, USA.

Hamel, G., and L. Välikangas. 2003. The quest for resilience. Harvard Business Review 81(9):52-63.

Hammer, M., A. M. Jansson, and B.-O. Jansson. 1993. Diversity change and sustainability: implications for fisheries. Ambio 22:97-105.

Hanna, S., C. Folke, and K.-G. Mäler, editors. 1996. Rights to nature: ecological, economic, cultural, and political principles of institutions for the environment. Island, Washington D.C., USA.

Hansen, J., M. Sato, and R. Ruedy. 2012. Perception of climate change. Proceedings of the National Academy of Sciences of the USA 109:E2415-E2423. http://dx.doi.org/10.1073/pnas.1205276109

Hegmon, M., M. A. Peeples, A. P. Kinzig, S. Kulow, C. M. Meegan, and M. Nelson. 2008. Social transformation and its human costs in the prehispanic U.S. Southwest. American Anthropologist 110:313-324. http://dx.doi.org/10.1111/ j.1548-1433.2008.00041.X

Hentati-Sundberg, J., J. Hjelm, W. J. Boonstra, and H. Österblom. 2015. Management forcing increased specialization in a fishery system. Ecosystems 18:45-61. http://dx.doi.org/10.1007/s10021-014-9811-3
Hill, M., and N. L. Engle. 2013. Adaptive capacity: tensions across scales. Environmental Policy and Governance 23:177-192. http:// dx.doi.org/10.1002/eet.1610

Hobman, E. V., and I. Walker. 2015. Stasis and change: social psychological insights into social-ecological resilience. Ecology and Society 20(1):39. http://dx.doi.org/10.5751/es-07260-200139

Holland, J. H. 1992. Complex adaptive systems. Daedalus 121:17-30.

Holland, J. H. 1995. Hidden order: how adaptation builds complexity. Helix Books/Perseus, Jackson, Tennessee, USA

Holling, C. S. 1973. Resilience and stability of ecological systems. Annual Review of Ecology and Systematics 4:1-23. http://dx.doi. org/10.1146/annurev.es.04.110173.000245

Holling, C. S., editor. 1978. Adaptive environmental assessment and management. Wiley, London, UK.

Holling, C. S. 1986. The resilience of terrestrial ecosystems: local surprise and global change. Pages 292-317 in W. C. Clark and R. E. Munn, editors. Sustainable development of the biosphere. Cambridge University Press, Cambridge, UK.

Holling, C. S. 1995. An ecologist's view of the Malthusian conflict. Pages 79-103 in K. Lindahl Kiessling and H. Landberg, editors. Population, economic development and the environment. Oxford University Press, Oxford, UK.

Holling, C. S., F. Berkes, and C. Folke. 1998. Science, sustainability, and resource management. Pages 342-362 in F. Berkes and C. Folke, editors. Linking social and ecological systems: management practices and social mechanisms for building resilience. Cambridge University Press, Cambridge, UK

Holling, C. S, and A. D. Chambers. 1973. Resource science: the nurture of an infant. BioScience 23:13-20. http://dx.doi. org/10.2307/1296362

Holling, C. S., and G. K. Meffe. 1996. Command and control and the pathology of natural resource management. Conservation Biology 10:328-337. http://dx.doi.org/10.1046/j.1523-1739.1996.10020328. $\underline{\mathrm{X}}$

Holling, C. S., D. W. Schindler, B. H. Walker, and J. Roughgarden. 1995. Biodiversity in the functioning of ecosystems: an ecological synthesis. Pages 44-83 in C. A. Perrings, K.-G. Mäler, C. Folke, C. S. Holling, and B.-O. Jansson, editors. Biodiversity loss: ecological and economic issues. Cambridge University Press, Cambridge, UK. http://dx.doi.org/10.1017/cbo9781139174329.005

Homer-Dixon, T., B. Walker, R. Biggs, A.-S. Crépin, C. Folke, E. F. Lambin, G. D. Peterson, J. Rockström, M. Scheffer, W. Steffen, and M. Troell. 2015. Synchronous failure: the emerging causal architecture of global crisis. Ecology and Society 20(3):6. http:// dx.doi.org/10.5751/es-07681-200306

Hornborg, A., J. R. McNeill, and J. Martinez-Alier, editors. 2007. Rethinking environmental history: world-system history and global environmental change. Altamira, Plymouth, UK.

Hughes, T. P., A. H. Baird, D. R. Bellwood, M. Card, S. R. Connolly, C. Folke, R. Grosberg, O. Hoegh-Guldberg, J. B. C. Jackson, J. Kleypas, J. M. Lough, P. Marshall, M. Nyström, S. R. Palumbi, J. M. Pandolfi, B. Rosen, and J. Roughgarden. 2003. 
Climate change, human impacts, and the resilience of coral reefs. Science 301:929-933. http://dx.doi.org/10.1126/science.1085046

Hughes, T. P., C. Linares, V. Dakos, I. A. van de Leemput, and E. H. van Nes. 2013. Living dangerously on borrowed time during slow, unrecognized regime shifts. Trends in Ecology and Evolution 28:149-155. http://dx.doi.org/10.1016/j.tree.2012.08.022

Hughes, T. P., M. J. Rodrigues, D. R. Bellwood, D. Ceccarelli, O. Hoegh-Guldberg, L. McCook, N. Moltschaniwskyj, M. S. Pratchett, R. S. Steneck, and B. Willis. 2007. Phase shifts, herbivory, and the resilience of coral reefs to climate change. Current Biology 17:360-365. http://dx.doi.org/10.1016/j.cub.2006.12.049

Huitema, D., E. Mostert, W. Egas, S. Moellenkamp, C. PahlWostl, and R. Yalcin. 2009. Adaptive water governance: assessing the institutional prescriptions of adaptive (co-)management from a governance perspective and defining a research agenda. Ecology and Society 14(1):26 http://dx.doi.org/10.5751/es-02827-140126

Janssen, M. A. 2002. Complexity and ecosystem management. Edward Elgar, Cheltenham, UK.

Janssen, M. A. 2007. An update on the scholarly networks on resilience, vulnerability, and adaptation within the human dimensions of global environmental change. Ecology and Society 12(2):9. http://dx.doi.org/10.5751/es-02099-120209

Janssen, M. A., and M. Scheffer. 2004. Overexploitation of renewable resources by ancient societies and the role of sunk-cost effects. Ecology and Society 9(1):6. http://dx.doi.org/10.5751/ $\underline{\text { es-00620-090106 }}$

Jansson, A. 2013. Reaching for a sustainable, resilient urban future using the lens of ecosystem services. Ecological Economics 86:285-291. http://dx.doi.org/10.1016/j.ecolecon.2012.06.013

Jansson, Å., and S. Polasky. 2010. Quantifying biodiversity for building resilience for food security in urban landscapes: getting down to business. Ecology and Society 15(3):20. [online] URL: http://www.ecologyandsociety.org/vol15/iss3/art20/

Jouffray, J. B., M. Nyström, A. V. Norström, I. D. Williams, L. M. Wedding, J. N. Kittinger, and G. J. Williams. 2015. Identifying multiple coral reef regimes and their drivers across the Hawaiian archipelago. Philosophical Transactions of the Royal Society B 370:20130268. http://dx.doi.org/10.1098/rstb.2013.0268

Karpouzoglou, T., A. Dewulf, and J. Clark. 2016. Advancing adaptive governance of social-ecological systems through theoretical multiplicity. Environmental Science \& Policy 57:1-9. http://dx.doi.org/10.1016/j.envsci.2015.11.011

Kates, R. W., and W. C. Clark. 1996. Environmental surprise: expecting the unexpected? Environment 38:6-34. http://dx.doi. org/10.1080/00139157.1996.9933458

Kates, R. W., W. R. Travis, and T. J. Wilbanks. 2012. Transformational adaptation when incremental adaptations to climate change are insufficient. Proceedings of the National Academy of Sciences of the USA 109:7156-7161. http://dx.doi. org/10.1073/pnas.1115521109

Kelly, P. M., and W. N. Adger. 2000. Theory and practice in assessing vulnerability to climate change and facilitating adaptation. Climatic Change 47:325-352. http://dx.doi. org/10.1023/A:1005627828199
Keys, P. W., R. J. van der Ent, L. J. Gordon, H. Hoff, R. Nikoli, and H. H. G. Savenije. 2012. Analyzing precipitation-sheds to understand the vulnerability of rainfall dependent regions. Biogeosciences 9:733-746. http://dx.doi.org/10.5194/bg-9-733-2012

Keys, P. W., L. Wang-Erlandsson, and L. J. Gordon. 2016. Revealing invisible water: moisture recycling as an ecosystem service. PLoS ONE 11(3):e0151993. http://dx.doi.org/10.1371/ journal.pone.0151993

King, C. A. 2008. Community resilience and contemporary agriecological systems: reconnecting people and food, and people with people. Systems Research and Behavioral Science 25:111-124. http://dx.doi.org/10.1002/sres.854

Lade, S. J., S. Niiranen, J. Hentati-Sundberg, T. Blenckner, W. J. Boonstra, K. Orach, M. F. Quaas, H. Österblom, and M. Schlüter. 2015. An empirical model of the Baltic Sea reveals the importance of social dynamics for ecological regime shifts. Proceedings of the National Academy of Sciences of the USA 112:11120-11125. http://dx.doi.org/10.1073/pnas.1504954112

Lade, S. J., A. Tavoni, S. A. Levin, and M. Schlüter. 2013. Regime shifts in a social-ecological system. Theoretical Ecology 6:359-372. http://dx.doi.org/10.1007/s12080-013-0187-3

Laliberte, E., J. A. Wells, F. DeClerck, D. J. Metcalfe, C. P. Catterall, C. Queiroz, I. Aubin, S. P. Bonser, Y. Ding, J. M. Fraterrigo, S. McNamara, J. W. Morgan, D. S. Merlos, P. A. Vesk, and M. M. Mayfield. 2010. Land-use intensification reduces functional redundancy and response diversity in plant communities. Ecology Letters 13:76-86. http://dx.doi.org/10.1111/ j.1461-0248.2009.01403.X

Lambin, E. F., and P. Meyfroid. 2011. Global land use change, economic globalization, and the looming land scarcity. Proceedings of the National Academy of Sciences of the USA 108:3465-3472. http://dx.doi.org/10.1073/pnas.1100480108

Lansing, J. S., and J. N. Kremer. 1993. Emerging properties of Balinese water temple networks: coadaptation on a rugged fitness landscape. American Anthropologist 95:97-114. http://dx.doi. org/10.1525/aa.1993.95.1.02a00050

Lazarus, E. D. 2014. Land grabbing as a driver of environmental change. Area 46:74-82. http://dx.doi.org/10.1111/area.12072

Leach, M., J. Rockström, P. Raskin, I. Scoones, A. C. Stirling, A. Smith, J. Thompson, E. Millstone, A. Ely, E. Arond, C. Folke, and P. Olsson. 2012. Transforming innovation for sustainability. Ecology and Society 17(2):11. http://dx.doi.org/10.5751/ es-04933-170211

Leach, M., I. Scoones, and A. Stirling. 2010. Dynamic sustainabilities: technology, environment, social justice. Routledge, London, UK.

Lebel, L., J. M. Anderies, B. Campbell, C. Folke, S. HatfieldDodds, T. P. Hughes, and J. Wilson. 2006. Governance and the capacity to manage resilience in regional social-ecological systems. Ecology and Society 11(1):19. http://dx.doi.org/10.5751/ es-01606-110119

Leichenko, R. 2011. Climate change and urban resilience. Current Opinion in Environmental Sustainability 3:164-168. http://dx.doi. org/10.1016/j.cosust.2010.12.014 
Lenton, T. M., H. Held, E. Kriegler, J. W. Hall, W. Lucht, S. Rahmstorf, and H. J. Schellnhuber. 2008. Tipping elements in the Earth's climate system. Proceedings of the National Academy of Sciences of the USA 105:1786-1793. http://dx.doi.org/10.1073/ pnas.0705414105

Leslie, P., and J. T. McCabe. 2013. Response diversity and resilience in social-ecological systems. Current Anthropology 54:114-143. http://dx.doi.org/10.1086/669563

Levin, S., T. Xepapadeas, A.-S. Crépin, J. Norberg, A. de Zeeuw, C. Folke, T. P. Hughes, K. Arrow, S. Barrett, G. Daily, P. Ehrlich, N. Kautsky, K.-G. Mäler, S. Polasky, M. Troell, J. Vincent, and B. H. Walker. 2013. Social-ecological systems as complex adaptive systems: modeling and policy implications? Environment and Development Economics 18:111-132. http://dx.doi.org/10.1017/ $\underline{\text { S1355770X12000460 }}$

Levin, S. A. 1998. Ecosystems and the biosphere as complex adaptive systems. Ecosystems 1:431-436. http://dx.doi.org/10.1007/ $\underline{\mathrm{s} 100219900037}$

Levin, S. A., S. Barrett, S. Aniyar, W. Baumol, C. Bliss, B. Bolin, P. Dasgupta, P. R. Ehrlich, C. Folke, I.-M. Gren, C. S. Holling, A. M. Jansson, B.-O. Jansson, K.-G. Mäler, D. Martin, C. Perrings, and E. Sheshinsky. 1998. Resilience in natural and socioeconomic systems. Environment and Development Economics 3:221-262. http://dx.doi.org/10.1017/S1355770X98240125

Liu, J., T. Dietz, S. R. Carpenter, M. Alberti, C. Folke, E. Moran, A. C. Pell, P. Deadman, T. Kratz, J. Lubchenco, E. Ostrom, Z. Ouyang, W. Provencher, C. L. Redman, S. H. Schneider, and W. W. Taylor. 2007. Complexity of coupled human and natural systems. Science 317:1513-1516. http://dx.doi.org/10.1126/ science. 1144004

Liu, J., V. Hull, M. Batistella, R. DeFries, T. Dietz, F. Fu, T. W. Hertel, R. C. Izaurralde, E. F. Lambin, S. Li, L. A. Martinelli, W. J. McConnell, E. F. Moran, R. Naylor, Z. Ouyang, K. R. Polenske, A. Reenberg, G. de Miranda Rocha, C. S. Simmons, P. H. Verburg, P. M. Vitousek, F. Zhang, and C. Zhu. 2013. Framing sustainability in a telecoupled world. Ecology and Society 18 (2):26. http://dx.doi.org/10.5751/es-05873-180226

Liu, W. 2014. The application of resilience assessment: resilience of what, to what, with what? A case study based on Caledon, Ontario, Canada. Ecology and Society 19(4):21. http://dx.doi. org/10.5751/ES-06843-190421

Lockwood, M., M. Mitchell, S. A. Moore, and S. Clement. 2014. Biodiversity governance and social-ecological system dynamics: transformation in the Australian Alps. Ecology and Society 19 (2):13. http://dx.doi.org/10.5751/es-06393-190213

Loorbach, D. 2007. Transition management: new mode of governance for sustainable development. International Books, Utrecht, The Netherlands.

Lorenz, D. F. 2013. The diversity of resilience: contributions from a social science perspective. Natural Hazards 67:7-24. http://dx. doi.org/10.1007/s11069-010-9654-y

Lubchenco, J. 1998. Entering the century of the environment: a new social contract for science. Science 279:491-497. http://dx. doi.org/10.1126/science.279.5350.491
Ludwig, D., D. D. Jones, and C. S. Holling. 1978. Qualitativeanalysis of insect outbreak systems: spruce budworm and forest. Journal of Animal Ecology 47:315-332 http://dx.doi.org/10.2307/3939

Ludwig, D., M. Mangel, and B. Haddad. 2001. Ecology, conservation, and public policy. Annual Review of Ecology and Systematics 32:481-517. http://dx.doi.org/10.1146/annurev. ecolsys.32.081501.114116

Lundberg, J., and F. Moberg. 2003. Mobile link organisms and ecosystem functioning: implications for ecosystem resilience and management. Ecosystems 6:87-98. http://dx.doi.org/10.1007/ s10021-002-0150-4

Luthe, T., and R. Wyss. 2015. Introducing adaptive waves as a concept to inform mental models of resilience. Sustainability Science 10:673-685. http://dx.doi.org/10.1007/s11625-015-0316-6

Lyon, C. 2014. Place systems and social resilience: a framework for understanding place in social adaptation, resilience, and transformation. Society \& Natural Resources 27:1009-1023. http://dx.doi.org/10.1080/08941920.2014.918228

Lyon, C., and J. R. Parkins. 2013. Toward a social theory of resilience: social systems, cultural systems, and collective action in transitioning forest-based communities. Rural Sociology 78:528-549. http://dx.doi.org/10.1111/ruso.12018

Mäler, K.-G., and C.-Z. Li. 2010. Measuring sustainability under regime shift uncertainty: a resilience pricing approach. Environment and Development Economics 15:707-719. http://dx. doi.org/10.1017/S1355770X10000318

Marcus, L., and J. Colding. 2014. Toward an integrated theory of spatial morphology and resilient urban systems. Ecology and Society 19(4):55. http://dx.doi.org/10.5751/es-06939-190455

Margis, K. 2010. Community resilience: an indicator of social sustainability. Society \& Natural Resources 23:401-416. http://dx. doi.org/10.1080/08941920903305674

Marshall, N. A., S. E. Park, W. N. Adger, K. Brown, and S. M. Howden. 2012. Transformational capacity and the influence of place and identity. Environmental Research Letters 7:034022. http://dx.doi.org/10.1088/1748-9326/7/3/034022

Marshall, N. A., and C. J. Stokes. 2014. Influencing adaptation processes on the Australian rangelands for social and ecological resilience. Ecology and Society 19(2):14. http://dx.doi. org/10.5751/es-06440-190214

Marston, J. M. 2015. Modeling resilience and sustainability in ancient agricultural systems. Journal of Ethnobiology 35:585-605. http://dx.doi.org/10.2993/etbi-35-03-585-605.1

Mathevet, R., M. Etienne, T. Lynam, and C. Calvet. 2011. Water management in the Camargue Biosphere Reserve: insights from comparative mental models analysis. Ecology and Society 16 (1):43. http://dx.doi.org/10.5751/es-04007-160143

Mathevet, R., J. Thompson, O. Delanoë, M. Cheylan, C. GilFourrier, and M. Bonnin. 2010. La solidarité écologique: un nouveau concept pour une gestion intégrée des parcs nationaux et des territoires. Natures Sciences Sociétés 18:424-433. http://dx. doi.org/10.1051/nss/2011006 
Mathevet, R., J. D. Thompson, C. Folke, and S. Chapin III. 2016. Protected areas and their surrounding territory: socioecological systems in the context of ecological solidarity. Ecological Applications 26:5-16. http://dx.doi.org/10.1890/14-0421

Matson, P., W. C. Clark, and K. Andersson. 2016. Pursuing sustainability: a guide to the science and practice. Princeton University Press, Princeton, New Jersey, USA.

McPhearson, T., E. Andersson, T. Elmqvist, and N. Frantzeskaki. 2015. Resilience of and through urban ecosystem services. Ecosystem Services 12:152-156. http://dx.doi.org/10.1016/j. ecoser.2014.07.012

McSweeney, K., and O. T. Coomes. 2011. Climate-related disaster opens a window of opportunity for rural poor in northeastern Honduras. Proceedings of the National Academy of Sciences of the USA 108:5203-5208. http://dx.doi.org/10.1073/pnas.1014123108

McWilliam, E. 2009. Teaching for creativity: from sage to guide to meddler. Asia Pacific Journal of Education 29:281-293. http:// dx.doi.org/10.1080/02188790903092787

Meerow, S., and J. P. Newell. 2015. Resilience and complexity: a bibliometric review and prospects for industrial ecology. Journal of Industrial Ecology 19:236-251. http://dx.doi.org/10.1111/ jiec. 12252

Meijerink, S., and D. Huitema. 2010. Policy entrepreneurs and change strategies: lessons from sixteen case studies of water transitions around the globe. Ecology and Society 15(2):21. http:// dx.doi.org/10.5751/es-03509-150221

Merrie, A., D. C. Dunn, M. Metian, A. M. Boustany, Y. Takei, A. O. Elferink, Y. Ota, V. Christensen, P. N. Halpin, and H. Österblom. 2014. An ocean of surprises: trends in human use, unexpected dynamics and governance challenges in areas beyond national jurisdiction. Global Environmental Change 27:19-31. http://dx.doi.org/10.1016/j.gloenvcha.2014.04.012

Merrie, A., and P. Olsson. 2014. An innovation and agency perspective on the emergence and spread of Marine Spatial Planning. Marine Policy 44:366-374. http://dx.doi.org/10.1016/j. marpol.2013.10.006

Michon, G. 2011. Revisiting the resilience of chestnut forests in Corsica: from social-ecological systems theory to political ecology. Ecology and Society 16(2):5. http://dx.doi.org/10.5751/ es-04087-160205

Miller, F., H. Osbahr, E. Boyd, F. Thomalla, S. Bharwani, G. Ziervogel, B. Walker, J. Birkmann, S. Van der Leeuw, J. Rockström, J. Hinkel, T. Downing, C. Folke, and D. Nelson. 2010. Resilience and vulnerability: complementary or conflicting concepts? Ecology and Society 15(3):11. [online] URL: http:// www.ecologyandsociety.org/vol15/iss3/art11/

Mitchell, M., R. Griffith, P. Ryan, G. Walkerden, B. Walker, V. A. Brown, and S. Robinson. 2014. Applying resilience thinking to natural resource management through a "planning-by-doing “ framework. Society \& Natural Resources 27:299-314. http://dx. doi.org/10.1080/08941920.2013.861556

Moberg, F., and C. Folke. 1999. Ecological services of coral reef ecosystems. Ecological Economics 29:215-233. http://dx.doi. org/10.1016/S0921-8009(99)00009-9
Moore, M.-L., O. Tjornbo, E. Enfors, C. Knapp, J. Hodbod, J. A. Baggio, A. Norström, P. Olsson, and D. Biggs. 2014. Studying the complexity of change: toward an analytical framework for understanding deliberate social-ecological transformations. Ecology and Society 19(4):54. http://dx.doi.org/10.5751/ es-06966-190454

Nayak, P. K., L. E. Oliveira, and F. Berkes. 2014. Resource degradation, marginalization, and poverty in small-scale fisheries: threats to social-ecological resilience in India and Brazil. Ecology and Society 19(2):73. http://dx.doi.org/10.5751/ es-06656-190273

Nelson, D. R., W. N. Adger, and K. Brown. 2007. Adaptation to environmental change: contributions of a resilience framework. Annual Review of Environment and Resources 32:395-419. http:// dx.doi.org/10.1146/annurev.energy.32.051807.090348

Nemec, K. T., J. Chan, C. Hoffman, T. L. Spanbauer, J. A. Hamm, C. R. Allen, T. Hefley, D. Pan, and P. Shrestha. 2013. Assessing resilience in stressed watersheds. Ecology and Society 19(1):34. http://dx.doi.org/10.5751/es-06156-190134

Norberg, J., and G. Cumming, editors. 2008. Complexity theory for a sustainable future. Columbia University Press, New York, New York, USA.

Norgaard, R. B. 1989. The case for methodological pluralism. Ecological Economics 1:37-57. http://dx.doi.org/10.1016/0921-8009 (89)90023-2

Norgaard, R. B. 1994. Development betrayed: the end of progress and a coevolutionary revisioning of the future. Routledge, San Francisco, California, USA.

Norris, F. H., S. P. Stevens, B. Pfefferbaum, K. F. Wyche, and R. L. Pfefferbaum. 2008. Community resilience as a metaphor, theory, set of capacities, and strategy for disaster readiness. American Journal of Community Psychology 41:127-150. http:// dx.doi.org/10.1007/s10464-007-9156-6

Norström, A., M. Nyström, J. Lokrantz, and C. Folke. 2009. Alternative states on coral reefs: beyond coral-macroalgal phase shifts. Marine Ecology Progress Series 376:295-306. http://dx. doi. org/10.3354/meps07815

Nykvist, B., and J. von Heland. 2014. Social-ecological memory as a source of general and specified resilience. Ecology and Society 19(2):47. http://dx.doi.org/10.5751/es-06167-190247

Nyström, M., and C. Folke. 2001. Spatial resilience of coral reefs. Ecosystems 4:406-417. http://dx.doi.org/10.1007/s10021-001-0019$\mathrm{y}$

Nyström, M., C. Folke, and F. Moberg. 2000. Coral reef disturbance and resilience in a human dominated environment. Trends in Ecology and Evolution 15:413-417. http://dx.doi. org/10.1016/S0169-5347(00)01948-0

Nyström, M., N. A. J. Graham, J. Lokrantz, and A. V. Norström. 2008. Capturing the cornerstones of coral reef resilience: linking theory to practice. Coral Reefs 27:795-809. http://dx.doi. org/10.1007/s00338-008-0426-z

Nyström, M., A. V. Norström, T. Bleckner, M. de la Torre Castro, J.S. Eklöf, C. Folke, H. Österblom, R. S. Steneck, M. Thyresson, 
and M. Troell. 2012. Confronting feedbacks of degraded marine ecosystems. Ecosystems 15:695-710. http://dx.doi.org/10.1007/ $\underline{\text { s10021-012-9530-6 }}$

O'Brien, K. 2012. Global environmental change II: from adaptation to deliberate transformation. Progress in Human Geography 36:667-676. http://dx.doi.org/10.1177/0309132511425767

O'Brien, K., B. Hayward, and F. Berkes. 2009. Rethinking social contracts: building resilience in a changing climate. Ecology and Society 14(2):12. http://dx.doi.org/10.5751/es-03027-140212

O'Brien, K., M. Pelling, A. Patwardhan, S. Hallegatte, A. Maskrey, T. Oki, U. Oswald-Spring, T. Wilbanks, P. Z. Yanda, C. Giupponi, et al. 2012. Toward a sustainable and resilient future. Pasges 437-486 in C. B. Field, V. Barros, T. F. Stocker, and Q. Dahe, editors. Managing the risks of extreme events and disasters to advance climate change adaptation. A Special Report of Working Groups I and II of the Intergovernmental Panel on Climate Change (IPCC). Cambridge University Press, Cambridge, UK. http://dx.doi.org/10.1017/cbo9781139177245.011

O'Connell, D., B. Walker, N. Abel, and N. Grigg. 2015. The resilience, adaptation and transformation assessment framework: from theory to application. CSIRO, Dickson, Australian Capital Territory, Australia.

Odum, E. P. 1989. Ecology and our endangered life-support systems. Sinauer Associates, Sunderland, Massachusetts, USA.

Olsson, P., and C. Folke. 2001. Local ecological knowledge and institutional dynamics for ecosystem management: a study of Lake Racken watershed, Sweden. Ecosystems 4:85-104. http://dx. doi.org/10.1007/s100210000061

Olsson, P., C. Folke, V. Galaz, T. Hahn, and L. Schultz. 2007. Enhancing the fit through adaptive co-management: creating and maintaining bridging functions for matching scales in the Kristianstads Vattenrike Biosphere Reserve, Sweden. Ecology and Society 12(1):28. http://dx.doi.org/10.5751/es-01976-120128

Olsson, P., C. Folke, and T. Hahn. 2004. Social-ecological transformation for ecosystem management: the development of adaptive co-management of a wetland landscape in southern Sweden. Ecology and Society 9(4):2. http://dx.doi.org/10.5751/ es-00683-090402

Olsson, P., C. Folke, and T. P. Hughes. 2008. Navigating the transition to ecosystem-based management of the Great Barrier Reef, Australia. Proceedings of the National Academy of Sciences of the USA 105:9489-9494. http://dx.doi.org/10.1073/pnas.0706905105

Olsson, P., V. Galaz, and W. J. Boonstra. 2014. Sustainability transformations: a resilience perspective. Ecology and Society 19 (4):1. http://dx.doi.org/10.5751/es-06799-190401

Olsson, P., L. H. Gunderson, S. R. Carpenter, P. Ryan, L. Lebel, C. Folke, and C. S. Holling. 2006. Shooting the rapids: navigating transitions to adaptive governance of social-ecological systems. Ecology and Society 11(1):18. http://dx.doi.org/10.5751/ es-01595-110118

Österblom, H., and C. Folke. 2013. Emergence of global adaptive governance for stewardship of regional marine resources. Ecology and Society 18(2):4. http://dx.doi.org/10.5751/es-05373-180204
Österblom, H., and C. Folke. 2015. Globalization, marine regime shifts and the Soviet Union. Philosophical Transactions of the Royal Society B, Biological Sciences. 370:20130278. http://dx.doi. org/10.1098/rstb.2013.0278

Österblom, H., J.-B. Jouffray, C. Folke, B. Crona, M. Troell, A. Merrie, and J. Rockström. 2015. Transnational corporations as keystone actors in marine ecosystem. PloS ONE 10(5):e0127533. http://dx.doi.org/10.1371/journal.pone.0127533

Österblom, H., M. Sissenwine, D. Symes, M. Kadin, T. Daw, and C. Folke. 2011. Incentives, social-ecological feedbacks and European fisheries. Marine Policy 35:568-574. http://dx.doi. org/10.1016/j.marpol.2011.01.018

Ostrom, E. 1990. Governing the commons: the evolution of institutions for collective actions. Cambridge University Press, New York, New York, USA. http://dx.doi.org/10.1017/ CBO9780511807763

Ostrom, E. 1999. Review of linking social and ecological systems: management practices and social mechanisms for building resilience. Ecological Economics 28:151-153. http://dx.doi. org/10.1016/S0921-8009(98)00096-2

Ostrom, E. 2005. Understanding institutional diversity. Princeton University Press, Princeton, New Jersey, USA.

Ostrom, E. 2007. A diagnostic approach for going beyond panaceas. Proceedings of the National Academy of Sciences of the USA 104:15181-15187. http://dx.doi.org/10.1073/pnas.0702288104

Ostrom, E. 2009. A general framework for analyzing sustainability of social-ecological systems. Science 325:419-422. http://dx.doi.org/10.1126/science.1172133

Oteros-Rozas, E., B. Martín-López, T. Daw, E. L. Bohensky, J. Butler, R. Hill, J. Martin-Ortega, A. Quinlan, F. Ravera, I. RuizMallén, M. Thyresson, J. Mistry, I. Palomo, G. D. Peterson, T. Plieninger, K. A. Waylen, D. Beach, I. C. Bohnet, M. Hamann, J. Hanspach, K. Hubacek, S. Lavorel, and S. Vilardy. 2015. Participatory scenario planning in place-based social-ecological research: insights and experiences from 23 case studies. Ecology and Society 20(4):32. http://dx.doi.org/10.5751/ES-07985-200432

Pahl-Wostl, C. 2007. Transitions towards adaptive management of water facing climate and global change. Water Resources Management 21:49-62. http://dx. doi.org/10.1007/s11269-006-9040-4

Pahl-Wostl, C., M. Craps, A. Dewulf, E. Mostert, D. Tabara, and T. Taillieu. 2007. Social learning and water resources management. Ecology and Society 12(2):5. http://dx.doi. org/10.5751/es-02037-120205

Pahl-Wostl, C., L. Lebel, C. Knieper, and E. Nikitina. 2012. From applying panaceas to mastering complexity: toward adaptive water governance in river basins. Environmental Science and Policy 23:24-34. http://dx.doi.org/10.1016/j.envsci.2012.07.014

Park, S. E., N. A. Marshall, E. Jakku, A. M. Dowd, S. M. Howden, E. Mendham, and A. Fleming. 2012. Informing adaptation responses to climate change through theories of transformation. Global Environmental Change 22:115-126. http://dx.doi. org/10.1016/j.gloenvcha.2011.10.003 
Parker, J. N., and E. J. Hackett. 2012. Hot spots and hot moments in scientific collaborations and social movements. American Sociological Review 77:21-44. http://dx.doi.org/10.1177/0003122411433763

Pelling, M. 2011. Adaptation to climate change: from resilience to transformation. Routledge, Oxford, UK.

Perrings, C. A., C. Folke, and K.-G. Mäler. 1992. The ecology and economics of biodiversity loss: the research agenda. Ambio 21:201-211.

Perrings, C. A., K.-G. Mäler, C. Folke, C. S. Holling, and B.-O. Jansson, editors. 1995. Biodiversity loss: ecological and economic issues. Cambridge University Press, Cambridge, UK. http://dx. doi.org/10.1017/cbo9781139174329

Peterson, G. 2000. Political ecology and ecological resilience: an integration of human and ecological dynamics. Ecological Economics 35:323-336. http://dx.doi.org/10.1016/S0921-8009(00) 00217-2

Peterson, G., C. R. Allen, and C. S. Holling. 1998. Ecological resilience, biodiversity, and scale. Ecosystems 1:6-18. http://dx. doi.org/10.1007/s100219900002

Peterson, G. D., S. R. Carpenter, and W. A. Brock. $2003 a$. Uncertainty and management of multi-state ecosystems: an apparently rational route to collapse. Ecology 84:1403-1411. http://dx.doi.org/10.1890/0012-9658(2003)084[1403:UATMOM]2.0. $\mathrm{CO} ; 2$

Peterson, G. D., G. S. Cumming, and S. R. Carpenter. $2003 b$. Scenario planning: a tool for conservation in an uncertain world. Conservation Biology 17:358-366. http://dx.doi.org/10.1046/ j.1523-1739.2003.01491.x

Pickett, S. T. A., M. L. Cadenasso, and J. M. Grove. 2004. Resilient cities: meaning, models, and metaphor for integrating the ecological, socio-economic, and planning realms. Landscape and Urban Planning 69:369-384. http://dx.doi.org/10.1016/j.

landurbplan.2003.10.035

Plieninger, T., and C. Bieling, editors. 2012. Resilience and the cultural landscape: understanding and managing change in humanshaped environments. Cambridge University Press, Cambridge, UK. http://dx.doi.org/10.1017/cbo9781139107778

Plieninger, T., C. Bieling, B. Ohnesorge, H. Schaich, C. Schleyer, and F. Wolff. 2013. Exploring futures of ecosystem services in cultural landscapes through participatory scenario development in the Swabian Alb, Germany. Ecology and Society 18(3):39. http://dx.doi.org/10.5751/es-05802-180339

Polasky, S., S. R. Carpenter, C. Folke, and B. Keeler. $2011 b$. Decision-making under great uncertainty: environmental management in an era of global change. Trends in Ecology and Evolution 26:398-404. http://dx.doi.org/10.1016/j.tree.2011.04.007

Polasky, S., A. de Zeeuw, and F. Wagener. 2011a. Optimal management with potential regime shifts. Journal of Environmental Economics and Management 62:229-240. http://dx. doi.org/10.1016/j.jeem.2010.09.004

$\mathrm{Pu}$, B., and Y. J. Qiu. 2016. Emerging trends and new developments on urban resilience: a bibliometric perspective. Current Urban Studies 4:36-52. http://dx.doi.org/10.4236/ cus.2016.41004
Quinlan, A. E., M. Berbés-Blázquez, L. J. Haider, and G. D. Peterson. 2015. Measuring and assessing resilience: broadening understanding through multiple disciplinary perspectives. Journal of Applied Ecology 23:677-687. http://dx.doi.org/10.1111/1365-2664.12550

Rathwell, K. J., and G. D. Peterson. 2012. Connecting social networks with ecosystem services for watershed governance: a social-ecological network perspective highlights the critical role of bridging organizations. Ecology and Society 17(2):24. http:// dx.doi.org/10.5751/es-04810-170224

Raudsepp-Hearne, C., G. D. Peterson, and E. M. Bennett. $2010 a$. Ecosystem service bundles for analyzing tradeoffs in diverse landscapes. Proceedings of the National Academy of Sciences of the USA 107:5242-5247. http://dx.doi.org/10.1073/pnas.0907284107

Raudsepp-Hearne, C., G. D. Peterson, M. Tengö, E. M. Bennett, T. Holland, K. Benessaiah, G. K. MacDonald, and L. Pfeifer. 2010b. Untangling the environmentalist's paradox: Why is human well-being increasing as ecosystem services degrade? BioScience 60:576-589. http://dx.doi.org/10.1525/bio.2010.60.8.4

Raymond, C. M., I. Fazey, M. S. Reed, L. C. Stringer, G. M. Robinson, and A. C. Evely. 2010. Integrating local and scientific knowledge for environmental management. Journal of Environmental Management 91:1766-1777. http://dx.doi.org/10.1016/ j.jenvman.2010.03.023

Redman, C. L. 2005. Resilience theory in archaeology. American Anthropologist 107:70-77. http://dx.doi.org/10.1525/aa.2005.107.1.070

Redman, C. L., and A. P. Kinzig. 2003. Resilience of past landscapes: resilience theory, society, and the longue durée.

Conservation Ecology 7(1):14. http://dx.doi.org/10.5751/ es-00510-070114

Reid, W. V., F. Berkes, T. Wilbanks, and D. Capistrano, editors. 2006. Bridging scales and knowledge systems. concepts and applications in ecosystem assessments. Island, Washington, D.C., USA.

Resilience Alliance. 2010. Assessing resilience in social-ecological systems: workbook for practitioners. Version 2.0. [online] URL: http://www.resalliance.org/resilience-assessment

Reyers, B., R. Biggs, G. S. Cumming, T. Elmqvist, A. P. Hejnowicz, and S. Polasky. 2013. Getting the measure of ecosystem services: a social-ecological approach. Frontiers in Ecology and the Environment 11:268-273. http://dx.doi.org/10.1890/120144

Reyers, B., J. L. Nel, P. J. O’Farrell, N. Sitas, and D. C. Nel. 2015. Navigating complexity through knowledge coproduction: mainstreaming ecosystem services into disaster risk reduction. Proceedings of the National Academy of Sciences of the USA 112:7362-7368. http://dx.doi.org/10.1073/pnas.1414374112

Richter, A., and V. Dakos. 2015. Profit fluctuations signal eroding resilience of natural resources. Ecological Economics 117:12-21. http://dx.doi.org/10.1016/j.ecolecon.2015.05.013

Rist, L., A. Felton, M. Nyström, M. Troell, R. A. Sponseller, J. Bengtsson, H. Österblom, R. Lindborg, P. Tidåker, D. G. Angeler, R. Milestad, and J. Moen. 2014. Applying resilience thinking to production ecosystems. Ecosphere 5:1-11. http://dx.doi. org/10.1890/es13-00330.1 
Robards, M., and L. Alessa. 2004. Timescapes of community resilience and vulnerability in the circumpolar north. Human Dimensions and the Arctic System 57:415-427. http://dx.doi. org/10.14430/arctic518

Robards, M. D., M. L. Schoon, C. L. Meek, and N. L. Engle. 2011. The importance of social drivers in the resilient provision of ecosystem services. Global Environmental Change 21:522-529. http://dx.doi.org/10.1016/j.gloenvcha.2010.12.004

Rocha, J. C., G. D. Peterson, and R. O. Biggs. 2015. Regime shifts in the Anthropocene: drivers, risks, and resilience. PLOS ONE 10: e0134639. http://dx.doi.org/10.1371/journal.pone.0134639

Rockström, J., M. Falkenmark, T. Allan, C. Folke, L. Gordon, A. Jägerskog, M. Kummu, M. Lannerstad, M. Meybeck, D. Molden, S. Postel, H. H. G. Savenije, U. Svedin, A. Turton, and O. Varis. 2014b. The unfolding water drama in the Anthropocene: towards a resilience based perspective on water for sustainability. Ecohydrology 7:1249-1261. http://dx.doi.org/10.1002/eco.1562

Rockström, J., M. Falkenmark, C. Folke, M. Lannerstad, J. Barron, E. Enfors, L. Gordon, J. Heinke, H. Hoff, and C. PahlWostl. 2014a. Water resilience for human prosperity. Cambridge University Press, Cambridge, UK. http://dx.doi.org/10.1017/ CBO9781139162463

Rockström, J., W. Steffen, K. Noone, A. Persson, F. S. Chapin III, E. F. Lambin, T. M. Lenton, M. Scheffer, C. Folke, H. J. Schellnhuber, B. Nykvist, C. A. de Wit, T. Hughes, S. van der Leeuw, H. Rodhe, S. Sörlin, P. K. Snyder, R. Costanza, U. Svedin, M. Falkenmark, L. Karlberg, R. W. Corell, V. J. Fabry, J. Hansen, B. H. Walker, D. Liverman, K. Richardson, P. Crutzen, and J. A. Foley. 2009. A safe operating space for humanity. Nature 461:472-475. http://dx.doi.org/10.1038/461472a

Rosen, F., and P. Olsson. 2013. Institutional entrepreneurs, global networks, and the emergence of international institutions for ecosystem-based management: the Coral Triangle Initiative. Marine Policy 38:195-204. http://dx.doi.org/10.1016/j.marpol.2012.05.036

Rotarangi, S. J., and J. Stephenson. 2014. Resilience pivots: stability and identity in a social-ecological-cultural system. Ecology and Society 19(1):28. http://dx.doi.org/10.5751/ $\underline{\text { es-06262-190128 }}$

Rumbach, A., and D. Foley. 2014. Indigenous institutions and their role in disaster risk reduction and resilience: evidence from the 2009 tsunami in American Samoa. Ecology and Society 19 (1):19 http://dx.doi.org/10.5751/ES-06189-190119

Scheffer, M. 2009. Critical transitions in nature and society. Princeton University Press, Princeton, New Jersey, USA.

Scheffer, M., S. Barrett, S. Carpenter, C. Folke, A. J. Greene, M. Holmgren, T. P. Hughes, S. Kosten, I. van de Leemput, D. Nepstad, E. H. van Nes, E. T. H. M. Peeters, and B. H. Walker. 2015. Creating a safe operating space for iconic ecosystems. Science 347:1317-1319 http://dx.doi.org/10.1126/science.aaa3769

Scheffer, M., and S. R. Carpenter. 2003. Catastrophic regime shifts in ecosystems: linking theory to observation. Trends in Ecology and Evolution 18:648-656. http://dx.doi.org/10.1016/j. tree.2003.09.002
Scheffer, M., S. R. Carpenter, J. Foley, C. Folke, and B. H. Walker. 2001. Catastrophic shifts in ecosystems. Nature 413:591-596. http://dx.doi.org/10.1038/35098000

Scheffer, M., S. R. Carpenter, T. M. Lenton, J. Bascompte, W. Brock, V. Dakos, J. van de Koppel, I. A. van de Leemput, S. A. Levin, E. H. van Nes, M. Pascual, and J. Vandermeer. 2012. Anticipating critical transitions. Science 338:344-348. http://dx. doi.org/10.1126/science. 1225244

Schill, C., T. Lindahl, and A.-S. Crépin. 2015. Collective action and the risk of ecosystem regime shifts: insights from a laboratory experiment. Ecology and Society 20(1):48. http://dx.doi. org/10.5751/es-07318-200148

Schlüter, M., and E. Herrfahrdt-Pähle. 2011. Exploring resilience and transformability of a river basin in the face of socioeconomic and ecological crisis: an example from the Amudarya river basin, Central Asia. Ecology and Society 16(1):32. http://dx.doi. org/10.5751/es-03910-160132

Scholes, R. J., B. Reyers, R. Biggs, M. J. Spierenburg, and A. Duriappah. 2013. Multi-scale and cross-scale assessments of social-ecological systems and their ecosystem services. Current Opinion in Environmental Sustainability 5:16-25. http://dx.doi. org/10.1016/j.cosust.2013.01.004

Schoon, M. L., and M. E. Cox. 2012. Understanding disturbances and responses in social-ecological systems. Society \& Natural Resources 25:141-155. http://dx.doi.org/10.1080/08941920.2010.549933

Schultz, L., C. Folke, and P. Olsson. 2007. Enhancing ecosystem management through social-ecological inventories: lessons from Kristianstads Vattenrike, Sweden. Environmental Conservation 34:140-152. http://dx.doi.org/10.1017/S0376892907003876

Schultz, L., C. Folke, H. Österblom, and P. Olsson. 2015. Adaptive governance, ecosystem management and natural capital. Proceedings of the National Academy of Sciences of the USA 112:7369-7374. http://dx.doi.org/10.1073/pnas. 1406493112

Schultz, L., and C. Lundholm. 2010. Learning for resilience? exploring learning opportunities in biosphere reserves. Environmental Education Research 16:645-663. http://dx.doi. org/10.1080/13504622.2010.505442

Scoones, I. 1999. New ecology and the social sciences: what prospects for a fruitful engagement? Annual Review of Anthropology 28:479-507. http://dx.doi.org/10.1146/annurev. anthro.28.1.479

Sellberg, M. M., C. Wilkinson, and G. D Peterson. 2015. Resilience assessment: a useful approach to navigate urban sustainability challenges. Ecology and Society 20(1):43. http://dx. doi.org/10.5751/es-07258-200143

Sendzimir, J., P. Magnuszewski, Z. Flachner, P. Balogh, G. Molnar, A. Sarvari, and Z. Nagy 2007. Assessing the resilience of a river management regime: informal learning in a shadow network in the Tisza River Basin. Ecology and Society 13(1):11. http://dx.doi.org/10.5751/es-02239-130111

Seto, K. C., A. Reenberg, C. G. Boone, M. Fragkias, D. Haase, T. Langanke, P. Marcotullio, D. K. Munroe, B. Olah, and D. Simon. 2012. Urban land teleconnections and sustainability. Proceedings of the National Academy of Sciences of the USA 109:7687-7692. http://dx.doi.org/10.1073/pnas.1117622109 
Simmie, J., and R. Martin. 2010. The economic resilience of regions: towards an evolutionary approach. Cambridge Journal of Regions, Economy and Society 3:27-43. http://dx.doi. org/10.1093/cjres/rsp029

Sjöstedt, M. 2015. Resilience revisited: taking institutional theory seriously. Ecology and Society 20(4):23. http://dx.doi.org/10.5751/ es-08034-200423

Smit, B., and J. Wandel. 2006. Adaptation, adaptive capacity and vulnerability. Global Environmental Change 16:282-292. http://dx. doi.org/10.1016/j.gloenvcha.2006.03.008

Smith, A., and A. Stirling. 2010. The politics of social-ecological resilience and sustainable socio-technical transitions. Ecology and Society 15(1):11. http://dx.doi.org/10.5751/es-03218-150111

Steffen, W., J. Crutzen, and J. R. McNeill. 2007. The Anthropocene: Are humans now overwhelming the great forces of nature? Ambio 36:614-621. http://dx.doi.org/10.1579/0044-7447 (2007)36[614:taahno]2.0.co;2

Steffen, W., Å. Persson, L. Deutsch, J. Zalasiewicz, M. Williams, K. Richardson, C. Crumley, P. Crutzen, C. Folke, L. Gordon, M. Molina, V. Ramanathan, J. Rockström, M. Scheffer, H. J. Schellnhuber, and U. Svedin. 2011. The Anthropocene: from global change to planetary stewardship. Ambio 40:739-761. http:// dx.doi.org/10.1007/s13280-011-0185-x

Steffen, W., K. Richardson, J. Rockström, S. Cornell, I. Fetzer, E. Bennett, R. Biggs, S. R. Carpenter, W. de Vries, C. A. de Wit, C. Folke, D. Gerten, J. Heinke, G. M. Mace, L. M. Persson, V. Ramanathan, B. Reyers, and S. Sörlin. 2015. Planetary boundaries: guiding human development on a changing planet. Science 347(6223). http://dx.doi.org/10.1126/science.1259855

Steneck, R. S., T. P. Hughes, J. E. Cinner, W. N. Adger, S. N. Arnold, F. Berkes, S. A. Boudreau, K. Brown, C. Folke, L. H. Gunderson, P. Olsson, M. Scheffer, E. Stephenson, B. H. Walker, J. Wilson, and B. Worm. 2011. Creation of a gilded trap by the high economic value of the Maine lobster fishery. Conservation Biology 25:904-912. http://dx.doi.org/10.1111/j.1523-1739.2011.01717. $\underline{\mathrm{x}}$

Sterner, T., M. Troell, J. Vincent, S. Aniyar, S. Barrett, W. Brock, S. R. Carpenter, K. Chopra, P. Ehrlich, M. Hoel, S. A. Levin, K.G. Mäler, J. Norberg, L. Pihl, T. Söderqvist, J. Wilen, and A. Xepapadeas. 2006. Quick fixes for the environment: part of the solution or part of the problem? Environment 48(10):20-27. http:// dx.doi.org/10.3200/envt.48.10.20-27

Stone-Jovicich, S. 2015. Probing the interfaces between the social sciences and social-ecological resilience: insights from integrative and hybrid perspectives in the social sciences. Ecology and Society 20(2):25. http://dx.doi.org/10.5751/es-07347-200225

Sundstrom, S. M., D. G. Angeler, A. S. Garmestani, J. H. Garcia, and C. R. Allen. 2014. Transdisciplinary application of cross-scale resilience. Sustainability 6:6925-6948. http://dx.doi.org/10.3390/ $\underline{\text { su6106925 }}$

Swart, R. J., P. Raskin, and J. Robinson. 2004. The problem of the future: sustainability science and scenario analysis. Global Environmental Change 14:137-146. http://dx.doi.org/10.1016/j. gloenvcha.2003.10.002
Takeuchi, K., T. Elmqvist, M. Hatakeyama, J. Kauffman, N. Turner, and D. Zhou. 2014. Using sustainability science to analyse social-ecological restoration in NE Japan after the great earthquake and tsunami of 2011. Sustainability Science 9:513-526. http://dx.doi.org/10.1007/s11625-014-0257-5

Tengö, M., E. S. Brondizio, T. Elmqvist, P. Malmer, and M. Spierenburg. 2014. Connecting diverse knowledge systems for enhanced ecosystem governance: the multiple evidence base approach. Ambio 43:579-591. http://dx.doi.org/10.1007/ $\underline{\text { s13280-014-0501-3 }}$

Thomas, D. S. G., and C. Twyman. 2005. Equity and justice in climate change adaptation amongst natural-resource-dependent societies. Global Environmental Change 15:115-124. http://dx.doi. org/10.1016/j.gloenvcha.2004.10.001

Thyresson, M., M. Nyström, and B. Crona. 2011. Trading with resilience: parrotfish trade and the exploitation of key-ecosystem processes in coral reefs. Coastal Management 39:396-411. http:// dx.doi.org/10.1080/08920753.2011.589226

Tidball, K. G. 2014. Seeing the forest for the trees: hybridity and social-ecological symbols, rituals and resilience in postdisaster contexts. Ecology and Society 19(4):25. http://dx.doi.org/10.5751/ es-06903-190425

Tidball, K. G., M. E. Krasny, E. Svendsen, L. Campbell, and K. Helphand. 2010. Stewardship, learning, and memory in disaster resilience. Environmental Education Research 16:591-609. http:// dx.doi.org/10.1080/13504622.2010.505437

Tidball, K. G., and R. Stedman. 2013. Positive dependency and virtuous cycles: from resource dependence to resilience in urban social-ecological systems. Ecological Economics 86:292-299. http://dx.doi.org/10.1016/j.ecolecon.2012.10.004

Tompkins, E. 2005. Planning for climate change in small islands: insights from national hurricane preparedness in the Cayman Islands. Global Environmental Change 15:139-149. http://dx.doi. org/10.1016/j.gloenvcha.2004.11.002

Treml, E. A., P. I. J. Fidelman, S. Kininmonth, J. A. Ekstrom, and Ö. Bodin. 2015. Analyzing the (mis)fit between the institutional and ecological networks of the Indo-West Pacific. Global Environmental Change 31:263-271. http://dx.doi.org/10.1016/j. gloenvcha.2015.01.012

Troell, M., R. Naylor, M. Metian, M. Beveridge, P. Tyedmers, C. Folke, K. Arrow, S. Barrett, A.-S. Crépin, P. Ehrlich, Å. Gren, N. Kautsky, S. Levin, K. Nyborg, H. Österblom, S. Polasky, M. Scheffer, B. Walker, T. Xepapadeas, and A. de Zeeuw. 2014. Does aquaculture add resilience to the global food system? Proceedings of the National Academy of Sciences of the USA 111:13257-13263. http://dx.doi.org/10.1073/pnas.1404067111

Trosper, R. L. 2005. Emergence unites ecology and society. Ecology and Society 10(1):14. http://dx.doi.org/10.5751/ es-01239-100114

Turner II, B. L., 2010. Vulnerability and resilience: coalescing or paralleling approaches for sustainability science? Global Environmental Change 20:570-576. http://dx.doi.org/10.1016/j. gloenvcha.2010.07.003 
Turner II, B. L., W. C. Clark, R. W. Kates, J. F. Richards, J. T. Mathews, and W. B. Meyer, editors. 1990. The Earth as transformed by human action: global and regional changes in the biosphere over the past 300 years. Cambridge University Press, Cambridge, UK.

Turner II, B. L., R. E. Kasperson, P. A. Matson, J. J. McCarthy, R. W. Corell, L. Christensen, N. Eckley, J. X. Kasperson, A. Luers, M. L. Martello, C. Polsky, A. Pulsipher, and A. Schiller. $2003 a$. A framework for vulnerability analysis in sustainability science. Proceedings of the National Academy of Sciences of the USA 100:8074-8079. http://dx.doi.org/10.1073/pnas. 1231335100

Turner, N. J., I. J. Davidson-Hunt, and M. O'Flaherty. $2003 b$. Living on the edge: ecological and cultural edges as sources of diversity for social-ecological resilience. Human Ecology 31:439-461. http://dx.doi.org/10.1023/A:1025023906459

Ullaha, I. I. T., I. Kuijt, and J. Freeman. 2015. Toward a theory of punctuated subsistence change. Proceedings of the National Academy of Sciences of the USA 112:9579-9584. http://dx.doi. org/10.1073/pnas.1503628112

van der Leeuw, S. E., and C. Aschan-Leygonie. 2005. A long-term perspective on resilience in socio-natural systems. Pages 227-264 in H. Liljeström and U. Svedin, editors. Micro, meso, macro: addressing complex systems couplings. World Scientific, Singapore. http://dx.doi.org/10.1142/9789812701404_0013

von Heland, J., and C. Folke. 2014. A social contract with the ancestors: culture and ecosystem services in southern Madagascar. Global Environmental Change 24:251-264. http://dx. doi.org/10.1016/j.gloenvcha.2013.11.003

Voß, J., and B. Bornemann. 2011. The politics of reflexive governance: challenges for designing adaptive management and transition management. Ecology and Society 16(2):9. [online] URL: http://www.ecologyandsociety.org/vol16/iss2/art9/main. $\underline{\mathrm{html}}$

Walker, B., C. S. Holling, S. R. Carpenter, and A. Kinzig. 2004. Resilience, adaptability and transformability in social-ecological systems. Ecology and Society 9(2):5. http://dx.doi.org/10.5751/ es-00650-090205

Walker, B., A. Kinzig, and J. Langridge. 1999. Plant attribute diversity, resilience, and ecosystem function: the nature and significance of dominant and minor species. Ecosystems 2:95-113. http://dx.doi.org/10.1007/s100219900062

Walker, B., and D. Salt. 2006. Resilience thinking. Island, Washington, D.C., USA.

Walker, B., and D. Salt. 2012. Resilience practice: building capacity to absorb disturbance and maintain function. Island, Washington, D.C., USA. http://dx.doi.org/10.5822/978-1-61091-231-0

Walker, B. H. 1992. Biological diversity and ecological redundancy. Conservation Biology 6:18-23. http://dx.doi. org/10.1046/j.1523-1739.1992.610018.x

Walker, B. H. 1993. Rangeland ecology: understanding and managing change. Ambio 22:80-87.

Walker, B. H., N. Abel, J. M. Anderies, and P. Ryan. $2009 a$. Resilience, adaptability, and transformability in the Goulburn-
Broken Catchment, Australia. Ecology and Society 14(1):12. [online] URL: http://www.ecologyandsociety.org/vol14/iss1/ $\underline{\operatorname{art} 12 /}$

Walker, B. H., J. M. Anderies, A. P. Kinzig, and P. Ryan, editors. 2006. Exploring resilience in social-ecological systems: comparative studies and theory development. Ecology and Society Special Feature 22. [online] URL: http://www. ecologyandsociety.org/issues/view.php/feature/22

Walker, B. H., S. Barrett, S. Polasky, V. Galaz, C. Folke, G. Engström, F. Ackerman, K. Arrow, S. R. Carpenter, K. Chopra, G. Daily, P. Ehrlich, T. Hughes, N. Kautsky, S. A. Levin, K.-G. Mäler, J. Shogren, J. Vincent, T. Xepapadeous, and A. de Zeeuw. $2009 \mathrm{~b}$. Looming global-scale failures and missing institutions. Science 325:1345-1346. http://dx.doi.org/10.1126/science.1175325

Walker, B. H., D. Ludwig, C. S. Holling and R. M. Peterman. 1981. Stability of semi-arid savanna grazing systems. Journal of Ecology 69:473-498. http://dx.doi.org/10.2307/2259679

Walker, B. H., L. Pearson, M. Harris, K.-G. Mäler, C. Z. Li, R. Biggs, and T. Baynes. 2010. Incorporating resilience in the assessment of inclusive wealth: an example from South East Australia. Environmental and Resource Economics 45:183-202. http://dx.doi.org/10.1007/s10640-009-9311-7

Walters, C. 1986. Adaptive management of renewable resources. Macmillan, New York, New York, USA.

Walters, C. J., and R. Hilborn. 1978. Ecological optimization and adaptive management. Annual Review of Ecology and Systematics 9:157-188. http://dx.doi.org/10.1146/annurev.es.09.110178.001105

Walters, C. J., and C. S. Holling. 1990. Large-scale management experiments and learning by doing. Ecology 71:2060-2068. http:// dx.doi.org/10.2307/1938620

Weichselgartner, J., and I. Kelman. 2015. Geographies of resilience: challenges and opportunities of a descriptive concept. Progress in Human Geography 39:249-267. http://dx.doi. org/10.1177/0309132513518834

West, S. P., and L. Schultz. 2015. Learning for resilience in the European Court of Human Rights: adjudication as an adaptive governance practice. Ecology and Society 20(1):31. http://dx.doi. org/10.5751/es-07190-200131

Westley, F., P. Olsson, C. Folke, T. Homer-Dixon, H. Vredenburg, D. Loorbach, J. Thompson, M. Nilsson, E. Lambin, J. Sendzimir, B. Banarjee, V. Galaz, and S. van der Leeuw. 2011. Tipping towards sustainability: emerging pathways of transformation. Ambio 40:762-780. http://dx.doi.org/10.1007/s13280-011-0186-9

Westley, F., O. Tjörnbo, L. Schultz, P. Olsson, C. Folke, B. Crona, and Ö. Bodin. 2013. A theory of transformative agency in linked social-ecological systems. Ecology and Society 18(3):27. http://dx. doi.org/10.5751/es-05072-180327

Westley, F., B. Zimmerman, and M. Quinn Patton. 2006. Getting to maybe: how the world is changed. Random House, Toronto, Ontario, Canada.

Wilkinson, C. 2012. Social-ecological resilience: insights and issues for planning theory. Planning Theory 11:148-169. http://dx. doi.org/10.1177/1473095211426274 
Wilkinson, C., L. Porter, and J. Colding. 2010. Metropolitan planning and resilience thinking: a practitioner's perspective. Critical Planning summer 2010:2-20.

Wilson, G. A. 2012. Community resilience, globalization, and transitional pathways of decision-making. Geoforum 43:1218-1231. http://dx.doi.org/10.1016/j.geoforum.2012.03.008

Winfree, R., and C. Kremen. 2009. Are ecosystem services stabilized by differences among species? A test using crop pollination. Proceedings of the Royal Society B 276:229-237. http://dx.doi.org/10.1098/rspb.2008.0709

Wise, R. M., I. Fazey, M. Stafford Smith, S. E. Park, H. C. Eakin, E. R. M. Archer Van Garderen, and B. Campbell. 2014. Reconceptualising adaptation to climate change as part of pathways of change and response. Global Environmental Change 28:325-336. http://dx.doi.org/10.1016/j.gloenvcha.2013.12.002

$\mathrm{Xu}$, L., and D. Marinova. 2013. Resilience thinking: a bibliometric analysis of socio-ecological research. Scientometrics 96:911-927. http://dx.doi.org/10.1007/s11192-013-0957-0

Young, O. R. 2010. Institutional dynamics: resilience, vulnerability and adaptation in environmental and resource regimes. Global Environmental Change 20:378-385. http://dx.doi. org/10.1016/j.gloenvcha.2009.10.001

Young, O. R. 2011. Effectiveness of international environmental regimes: existing knowledge, cutting-edge themes, and research strategies. Proceedings of the National Academy of Sciences of the USA 108:19853-19860. http://dx.doi.org/10.1073/pnas.1111690108

Young, O. R., F. Berkhout, G. C. Gallopin, M. A. Janssen, E. Ostrom, and S. van der Leeuw. 2006. The globalization of socioecological systems: an agenda for scientific research. Global Environmental Change 16:304-316. http://dx.doi.org/10.1016/j. gloenvcha.2006.03.004 